\title{
Narrative and Theory: Formalism's Recurrent Return
}

\section{Singh, Sahib}

2015

Singh , S 2015 , ' Narrative and Theory: Formalism's Recurrent Return ', British yearbook of pÿinternational law, vol. 84 , no. 1 , pp. 304343 .

http://hdl.handle.net/10138/174441

publishedVersion

Downloaded from Helda, University of Helsinki institutional repository.

This is an electronic reprint of the original article.

This reprint may differ from the original in pagination and typographic detail.

Please cite the original version. 
The British Yearbook of International Law (C) The Author 2014. Published by Oxford University Press. Available online at www.bybil.oxfordjournals.org

doi: I O. 1093/bybil/bruo28

\title{
Narrative and 'Theory: Formalism's RECURRENT RETURN
}

\author{
$B y \mathrm{SAHIB}_{\mathrm{S}} \mathrm{INGH}^{*}$
}

\section{INTRODUCTION}

Disciplines do not always appreciate being interrogated. International law's recent history might suggest that it is a little more liberal in this regard. The rise of intellectual projects that seek to question the discipline's assumptions, preferences and processes of professional knowledge production, has been a hallmark development since the late i 980 . And yet, as such critical projects have since proliferated and become subsumed - accepted by the discipline on its own terms - there has been another casualty. This is the near loss of a critical posture. What seemed relegated, perhaps marginalised, is the willingness to think about how we think (reflexivity) and to self-consciously practice this process to one's own theories and ideas (i.e. self-reflexivity). This state of affairs conditions current international legal theory. To combat this, I turn to narrative analysis as a critical method; a move that has the express purpose of engendering a specific form of responsibility in how ideas are expressed and understood within the discipline. This project is however distinct from current approaches in critical legal theory. I speak of a responsibility attached to those who attend to theory, concerned not only with making explicit the personal or cultural biases of the theorist, but also with making explicit how a theory constrains, is made to seem necessary, and how it imposes limits on our world view. Narrative analysis may be of considerable use in engendering such an ethic. Here, I chose to

* University of Cambridge [sahib.g.singh@gmail.com]. I would like to thank Andrea Bianchi, Martti Koskenniemi, Jason Beckett, Mario Prost, Geoff Gordon, Barrie Sander, David Kennedy, Mónica Garcia-Salmones, Umut Özsu, and the journal's reviewers for their detailed comments on earlier drafts of this paper. I am also thankful to John Haskell, Adil Hasan Khan and Andrew Lang for recommending authors and readings that have influenced this piece, as well as to the participants of the workshop 'Turf and Texture: Narrating the Legal International', held in Cambridge, UK in June 20I3. Finally, I am particularly grateful for the intellectual generosity and work of Philip Allott, who perhaps unbeknownst to him has greatly influenced parts of this piece. A substantially different version of this piece has appeared as an appendix in J d'Aspremont, Formalism and the Sources of International Law: A Theory of the Ascertainment of Legal Rules (OUP 2013), 236-26r. The task undertaken here is different in purpose and execution, even if it does still use d'Aspremont's book as a foundation. 
employ this method on a type of normative international legal theory that eschews reflexivity: contemporary formalism, specifically its Hartian variant, as outlined in Jean d'Aspremont's recent book Formalism and the Sources of International Law (FSIL). ${ }^{\mathrm{I}}$

Formalism has always held a privileged place in European international legal thinking. Its return to define contemporary debates within the discipline is a complex affair, but a consistent thread is the attempt to recapture the relative autonomy of the international legal discipline. ${ }^{2} \mathrm{It}$ is within this disciplinary moment that d'Aspremont's monograph emerges. This formalism is not an innocent theory, but intensely political in two distinct senses. First, it is a political position that situates itself in the drama of disciplinary governance: it is being used to sustain disciplinary autonomy. It has been deployed as the foundations of a contemporary culture of European resistance to empire. Second, it is imbued with specific biases because the contours of the theory are constructed and prefigured. Various forms of contemporary formalism anchor law's claim to autonomy in 'social practice', 'hermeneutic techniques', 'interpretive craft', 'argumentative practice' or even 'style'. But such conceptual apparatuses, naturalised precisely because they often seem obvious, are made to seem necessary, interpreted and filled in a constitutive act by a theorist. Both aspects of the political will be addressed in this article, and both attend to the question of reflexivity.

d'Aspremont's thesis is simple: how we ascertain the sources of international law ought to be a formalised process - it ought to be done by grounding them in the social practice of a wide-range of law-applying authorities. This is a thesis, not a general theory of international law (8). At its core, it is the application of the HLA Hart's jurisprudence to the sources of international law. Most of the book, however, is dedicated to opening up the conceptual space for this thesis. It is this exercise in demarcation that allows d'Aspremont to make claims on how other theories may or may not be relevant. This is done through various strategies of persuasion and specific aesthetic choices. More importantly, the persuasiveness and necessity of d'Aspremont's thesis owes a great deal to his

I J d'Aspremont, Formalism and the Sources of International Law: A Theory of the Ascertainment of Legal Rules (OUP 20I I). Page numbers of the book are referenced in parenthesis throughout this article.

${ }^{2}$ A selection of work includes: M Koskenniemi, The Gentle Civilizer of Nations: The Rise and Fall of International Law I870-1960 (CUP 2001), 474-494; M Koskenniemi, 'Miserable Comforters: International Relations as New Natural Law', (2009) I 5 European Journal of International Relations 395; J Klabbers, 'The Relative Autonomy of International Law or the Forgotten Politics of Interdisciplinarity', (2004) I Journal of International Law and International Relations 35; J Klabbers, 'Bridge Crack'd: A Critical Look at Interdisciplinary Relations', (2009) 23 International Relations I I9; J Crawford, 'International Law as a Discipline and Profession', (2012) Io6 ASIL Proc 47I; J Crawford, 'Chance, Order, Change: The Course of International Law, General Course on Public International Law', (2013) 365 Recueil des Cours de l'Académie de Droit International 9. For a critical commentary of this formalism see, S Singh, 'A Nostalgia for Autonomy' in A Nollkaemper, W Werner and J d'Aspremont (eds.), International Law as a Profession (CUP 2015 forthcoming). 
conceptual framework. It is the interrelated functioning of these two aspects of his monograph - how it sets the scene for a Hartian thesis on sources and the content of this thesis - that make it an apt text to explore how ideas are 'produced', 'sold' and 'consumed'.

This form allows d'Aspremont to make a mild, but important, intervention in the disciplinary discourse of international law. Mild because it acts as a gentle reminder that when we talk about what international law is, we must speak specifically of law - and not of economics, history, or philosophy - as grounded in identifiable rules and social facts. Important because it is representative of a mainstream realist approach to a specific disciplinary moment, where formalism is being used to resist deformalisation, empire and disciplinary colonisation. ${ }^{3}$ d'Aspremont's FSIL may not subscribe to each of these political agendas, but it cannot operate or be understood in complete absence of them. It does not emerge, after all, in a vacuum. The politics of its theory are better understood once FSIL is placed in relation to the other works of the author (on international legal positivism and epistemology), ${ }^{4}$ in relation to and as part of a network of other texts in the discursive field, ${ }^{5}$ and in given historical and political contexts. In short, the meaning of d'Aspremont's narrative emerges from both what is said and what is not said, ${ }^{6}$ from inside the text and outside of it, from both its form and its content.

In offering this account, I will first explore the contours of what it means to embrace narrative analysis as a critical method (Part I). This entails ordering the concepts around which this method functions, the politics behind this choice of method at this historical juncture and for the purpose of analysing the present text, and the enduring value it can have for how we think about ideas. The remainder of the article then applies narrative analysis to d'Aspremont's text. The ground covered is vast: from the pathological desire for coherence and its intimacy with the politics of method and the promise of progress (Part II), to the discipline's politics as conditioning FSIL's production and reception (Part III), and finally the arrested and unstated ideology that grounds d'Aspremont's Hartian method (Part IV). I aim to examine how specific strategies, concepts and conditions structure both the conceptual space around d'Aspremont's thesis and its content. The article concludes that it is the form of a theory that influences the legal mind, more than the substance of its claims. This must be appreciated if one is to grasp the intimate connection between ideas, imagination and action.

3 These are further explored in Singh, A Nostalgia for Autonomy.

$4 \mathrm{~J}$ d'Aspremont and J Kammerhofer, International Legal Positivism in a Post-modern World (CUP 20I4); J. d'Aspremont, 'Reductionist Legal Positivism and International Law', (2012) ro6 ASIL Proc 368; J d'Aspremont, 'Wording in International Law', (2012) 25 LJIL 575.

5 M Foucault, The Archaeology of Knowledge (A Sheridan Smith (trans.), Routledge, Abingdon 20II), 25-6.

${ }^{6}$ M Foucault, 'Le discours ne droit pas être pris comme...' in M Foucault, Dits et écrits (Vol. III), I976-79 (Gallimard, Paris 1994) I23. 


\section{Narrative Analysis as a Critical Method in Legal Theory}

Roland Barthes once observed that narrative 'is present at all times, in all places, in all societies; indeed narrative starts the very history of mankind...Like life itself, it is there, international, transhistorical, transcultural.' ${ }^{7}$ Narratives, then, are not only seemingly inescapable, in Barthes sense, but they are how we make sense of the world. They allow us to understand, explain and act within it. ${ }^{8}$ Narrative analysis is an analytical method that has been applied across a number of disciplines in recent years. ${ }^{9}$ Its methodological moorings, however, lie predominantly in literary criticism and historical theory. ${ }^{\circ \circ}$ Here, I draw upon the insights of these intellectual fields, but am careful to sustain the particularities of international legal theory. ${ }^{\text {II }}$ In this vein such theories are stories that let us see, and simultaneously hide, different worlds - all the while constituting us, the limits and potential of our imagination, and the law. To understand legal theories as narratives both opens up a specific set of questions and imports a bedevilled intellectual history. ${ }^{\text {I2 }}$ It requires us to ask both what knowledge a legal theory or project produces (which actors, political projects and biases are foregrounded) and how it produces this knowledge. It is only the latter that concerns me here.

The dominance of an idea depends on both the material factors that sustain it (e.g. its prevalence in the university, the provision of research funding grants, its usefulness to institutions of practice etc.) and the theory's form. The task in regards the latter is to ask and to demonstrate

7 R Barthes, 'An Introduction to a Structural Analysis of Narrative', (1975) 6 New Literary History 237, 237.

8 See also, F Jameson, The Political Unconscious: Narrative as a Socially Symbolic Act (Routledge, Abingdon 2002), xiii ('the all-informing process of narrative, which I take to be (here using the shorthand of philosophical idealism), the central function or instance of the human mind.').

9 See, J Phelan and P Rabinowitz (eds.), A Companion to Narrative Theory (Blackwell Publishing, Oxford 2005) I-I 7 .

ro Particular influences are: N Frye, Anatomy of Criticism: Four Essays (Princeton University Press I 957); Jameson, The Political Unconscious; P Macherey, A Theory of Literary Production (G Wall (trans.), Routledge \& Kegan Paul, London 1978) (all are concerned with narrative as used in literary criticism). Also see, H White, Metahistory: The Historical Imagination in Nineteenth-Century Europe ('The Johns Hopkins University Press 1975); H White, The Content of Form: Narrative Discourse and Historical Representation (The John Hopkins University Press I990); and H White, The Fiction of Narrative: Essays on History, Literature and Theory 1957-2007 (R. Doran (ed.), The Johns Hopkins University Press 2010).

${ }^{\text {I } ~ A t ~ t h e ~ o u t s e t ~ t h e r e ~ i s ~ a ~ d i f f e r e n c e ~ i n ~ c l a i m e d ~ f u n c t i o n s ~ o f ~ n a r r a t i v e ~ i n ~ t h e s e ~ f i e l d s . ~ I n ~ l i t e r a t u r e, ~}$ narrative moves in the realm of the fictive, of the figurative and of art; meaning is produced by allusions to reality. Historical work, in contrast, claims to explain past events, structures and process by representing them in narrative form. Narrative produces meaning in the former in its move from non-reality towards reality, and the converse is true for the latter. International legal theory requires the approach in each of these fields. Most legal theories begin from claims to reality, of both present and past, before moving towards a plausible fictive vision for the future of this same world; this movement and a legal theory's normative destination are both premised upon and configured by certain allusions to reality, as well as the claimed reality from which the theory initially emerged.

${ }^{2}$ H White, 'The Question of Narrative in Contemporary Historical Theory' in H White (ed.), The Content of Form: Narrative Discourse and Historical Representation (The Johns Hopkins University Press I990) 26-57. 
how a theory asserts its logic, how its conceptual apparatus and its utopia are constructed to appeal to our desires and intuitions, and how it - as a way of thinking about and understanding the world - becomes engrained, unconsciously assumed and/or embedded within our culture. To cognise the role that theories can and do play in constraining and/ or enabling our imagination, how they construct us just as they construct the law, strikes me as a task of some urgency. And whilst becoming selfconscious of this is a necessary first step, to practice theory with reflexivity, and hence responsibility, is the next.

Legal theories are stories: they are varying perspectives on what the law is, its past and its potential futures, to say nothing of what they say or presume of the social world. As narratives they are part history, part method and part ideology. When analysed as such, sufficient regard must be had to their form, whether poem, novel, speech, academic text, or other narrative forms. The content of the form shapes how a theory, or narrative, persuades. Here, I apply three broad principles of narrative analysis to a series of contemporary texts related to Hartian positivism.

First, narrative analysis does not seek to explain the text anew, or to discover its hidden meaning, or to simply dismantle the text in order to replace it with a demonstration of how it really produces meaning. ${ }^{\mathrm{I} 3} \mathrm{It}$ eschews the mindset and method of those claiming 'rightness', ${ }^{14}$ i.e. an authoritative interpretation of the text or law. Perhaps its politics, in this regard, is to demonstrate an epistemological rupture with the ruling rationalities in the social sciences (economics and science), as well as with the prevailing view in international legal disciplinary culture. To relinquish the perception that one can discover the true meaning of the text comes with the recognition that a narrative can and does produce a multiplicity of meanings. How a text mediates between these meanings provides an insight into how it may work on our imagination. ${ }^{15} \mathrm{~A}$ 'narrative compels precisely because it seems that it might have been different.' ${ }^{\text {' } 6}$

Second, narrative analysis embraces the complexity of the text; it does not reduce it to the intentions and choices of the author nor to any structuring models or visions of the world (law) that it may adopt, even if it does consciously highlight each of these. Instead, it recognises that a legal theory is comprised of the relationships between each of its component parts - its concepts, illusions and aesthetics. Each produces meanings in different ways; some appealing to and gaining their legitimacy

I3 Macherey, A Theory of Literary Production, 76-77.

I4 The idea of 'rightness' is embedded within legal culture; see D Kennedy, A Critique of Adjudication \{fin de siècle\} (Harvard University Press I 998) 364-368.

I5 P Ricoeur, 'Existence and Hermeneutics' in C Reagen and D Stewart (eds.), The Philosophy of Paul Ricoeur: An Anthology of his Work (Beacon Press, Boston 1978) 97, 98.

${ }^{16}$ Macherey, A Theory of Literary Production, 47. For a similar sentiment in regards the historiography of international law see, Koskenniemi, The Gentle Civilizer, 5. 
beyond the text, as well as through concrete, if contested, definition (e.g. concepts), whilst others can only take on different meanings depending on how they are deployed within the text (e.g. images, meaning illusive visions of the world). The relationships, and kinds of relationships, between these elements of a legal theory delineate the text's meaning(s) and hence its imaginative power. These relationships reflect the text's strategies and the author's narrative tactics, but they are not determined by the author's choice, or by various structures that infuse the text, such as emplotment (tragedy, comedy, satire, romance etc.) or linguistic protocol (metaphor, metonymy, synecdoche, irony etc.). ${ }^{17}$ Each of these may place constraints and possibilities for meaning on a text, but a legal theory's concepts, illusions and aesthetics take on new meanings and possibilities as they are set to work within the text and in the act of reading. Narrative analysis, as used here, does bring a stringent focus onto the conceptual strategies, narrative tactics and other epistemological and aesthetic choices made by d'Aspremont, but it does not place an undue and unjust burden on them. It resists simplifying the meaning and knowledge of the theoretical text to the intentions of its author, or to the visions of the world he a priori subscribes to and the meaning this imports.

Third and finally, narrative analysis seeks to look beyond a legal theory text's apparent coherence and unity, its apparent self-sufficiency, ${ }^{18}$ rather seeking to highlight and then breach its 'strategies of containment' ${ }^{19}$ Critical narrative analysis must go beyond the legal theoretical text in order to remain loyal to it. It must recognise the text is influenced by the nature and problems of the individual author's existence and functions. This is arguably one element of reflexivity - the foregrounding of the one's presuppositions and presumed dispositions. ${ }^{20}$ The text depends on these biases. It cannot do without them just as it cannot do without its 'ideological history, the history which generates the succession of questions and the thread of problematics' ${ }^{21}$ that seem to

${ }^{17}$ Much is to be learnt from Hayden White's idea of the author's 'poetic act', but this confuses the act of writing and composing a text, with that of reading it. It is also too formalist and structuralist for the approach taken here. See, White, Metahistory, 30-3 I: 'In order to figure "what really happened" in the past, therefore, the historian must first prefigure as a possible object of knowledge the whole set of events reported in the documents. This prefigurative act is poetic inasmuch as it is precognitive and precritical in the economy of the historian's own consciousness. It is also poetic insofar as it is constitutive of the structure that will subsequently be imaged in the verbal model offered by the historian as a representation and explanation of "what really happened" in the past. But it is constitutive not only of a domain which the historian can treat as a possible object of (mental) perception. It is also constitutive of the concepts he will use to identify the objects that inhabit that domain and to characterize the kinds of relationships they can sustain with one another. In the poetic act which precedes the formal analysis of the field, the historian both creates his object of analysis and predetermines the modality of the conceptual strategies he will use to explain it.' (original emphasis)

I 8 Macherey, A Theory of Literary Production, 4I.

I9 Jameson, The Political Unconscious, ii.

2o P Schlag, The Enchantment of Reason (Duke University Press I 998), I 26- I 39

2I Macherey, A Theory of Literary Production, 93. 
structure and define it. This history and these problematics, its place in a given discursive field amongst other texts, ${ }^{22}$ all infuse themselves into the legal theoretical text as it produces meaning; as it mediates the relationship between the explicit and the implicit, ${ }^{23}$ we must seek to probe the text for what it does not or cannot say (its unconscious, if you will) by reaching beyond it. ${ }^{24}$

These three principles of narrative analysis are better suited to the act of reading. They function better when applied to the texts of a given author, rather than the variety of texts that one finds in the discursive field of a given international legal theory. Their intended purpose, broadly speaking, is to serve as a tool-kit for those readers of theoretical texts that wish to think about how ideas are introduced into the discipline. This is but one route into reflexive inquiry about the discipline. But I advocate these principles, and apply them in the remainder of this article, with specific considerations and critical aspirations in mind - some of my own biases if you will.

At the forefront of these is a renewed appreciation for self-reflexivity and responsibility in international legal theory. Self-reflexivity is a philosophical posture adopted by the writer, the performer, the practicing actor - here, the legal theorist. Whilst reflexivity and self-reflexivity are concepts rooted in divergent and at times conflicting philosophical positions - from Nietzsche, Foucault, Derrida, Lyotard, and Bourdieu, to name a few - I only articulate it and draw upon it as a general intellectual posture. Philip Allott articulates philosophy as 'the self-contemplating of the human mind, a thinking thing thinking about its thinking, actor and spectator of its own mental events. ${ }^{25}$ To practice the act of thinking about thinking and applying it to one's thinking is the act of self-reflexivity. Being open to, aware of, and open about the ambitions, limits and prejudices of one's own ideas produces an ethic of responsibility. It is not enough to realise that one, as a scholar, is not neutral but rather constantly situated or that reality is not susceptible to neutral, objective, representation. ${ }^{26}$ Instead it is about being transparent about the choices and cultural biases - professional and personal - that animate

\footnotetext{
22 Foucault, The Archaeology of Knowledge, I Io- I I (he termed this more broadly, as the 'associated field').

${ }^{23}$ Ibid, 87; J Thompson, 'Language and Ideology: A Framework for Analysis', (1987) 35 The Sociological Review 5 I6, 520.

24 Macherey, A Theory of Literary Production, 77-80, 90-95 (though I reject Macherey's argument that this is a scientific enterprise, ibid, 52); Jameson, The Political Unconscious, xiii-ix.

25 P Allott, Eunomia: New Order for a New World (OUP 200I), xxix.

26 Normative legal theories with a descriptive dimension normally make a vague disclosure in this regard, and this has become an indentured caveat in social science methodology, even if it not taken seriously to heart in either. A claim to a modified objectivity is sustained. See e.g. J Trachtman, The Economic Structure of International Law (Harvard University Press 2008), 4 (noting 'illuminations are not neutral'); M Weber, "“Objectivity” in the Social Sciences' in M Weber, The Methodology of the Social Sciences (E Shils and H Finch (tr.), Free Press, New York I949), 49-I I 2.
} 
the theorist's conceptual apparatus, ideological stances and choice of aesthetics. Self-reflexivity is about acknowledging and being open about the impact of external factors and internal beliefs - to the extent that this inquiry is possible and useful - because after all, we cannot escape context. ${ }^{27}$

The conscious move to consider legal theory, not merely as a theory, but as narrative is one possible way in which self-reflexivity can be encouraged. It confronts, at an epistemological level, the essential structure of normative legal theory: namely, its claim be based on explanatory descriptive claims, which through a series of justificatory claims, require certain normative claims. Two challenges are made. First, that such normative legal theory does not descriptively explain the law, or aspects of the social world, but rather constructs it. 'The function of narrative is not to "represent", it is to constitute a spectacle. ${ }^{28}$ The focus is then shifted to the more self-conscious question of how this construction takes place. Second, to conceive of a legal theory as narrative is to acknowledge how its various component parts (the descriptive, normative, justificatory, as well as the conceptual, illusory and aesthetic) shape each other in their complex relations within such a text. They are not distinct and separable intellectual schemes or aspects of a theoretical text/narrative; rather these parts labour together to create the story that unfolds. The move to narrative overtly brings into sharp relief a theory's own process of production - how the imaginative, aesthetic and conceptual choices made by the author ${ }^{29}$ and the cultural conditions in which such choices were made, create the law we see. ${ }^{30}$ For a theorist to actively engage with this question of how, and to practice it, is the self-reflexive move that is advocated here. While it is reminiscent of those critical scholars that applied variations of discourse analysis, it is my hope that the text that follows may also be read to break, in important ways, from this tradition.

Recent critical scholarship has shown an appreciation of international legal theory as narrative. Martti Koskenniemi has chosen to accompany his historiographical turn with a move from theory to narrative. ${ }^{3 \mathrm{I}}$ The focus has been to urge the telling of new narratives to enable 'us to see

${ }_{27}$ This sentiment is perhaps found as we note a subtle shift in Allott's definition of philosophy from Eunomia, (at xxix) to his P Allott, The Health of Nations: Society and Law Beyond the State (CUP 2002) I44 ('Philosophy is the socially organized self-contemplating of the human mind' (underlined emphasis mine)). See also, S Winter, A Clearing in the Forest: Law, Life and Mind (University of Chicago Press, Chicago 2003), xiv-xv, 332-357.

${ }_{28}$ R Barthes, 'Introduction to the Structural Analysis of Narrative' quoted in H White, 'The Question of Narrative in Contemporary Historical Theory' in White, The Content of Form, 26-57, 37.

29 R West, 'Jurisprudence as Narrative: An Aesthetic Analysis of Modern Legal Theory', (I 985 ) 60 New York University Law Review I45, 203-2 I I (focusing on the imaginative choices).

$3 \circ$ White, The Question of Narrative in Contemporary Historical Theory, 35 and 43.

${ }^{\text {r }}$ Koskenniemi, The Gentle Civilizer, ro. See also, S Singh, 'The Politics of Martti Koskenniemi's Theory' in W Werner (ed.), Martti Koskenniemi and his Critics (20 I 5, forthcoming) (exploring the link between this move and the influence of pragmatism). 
things that were previously hidden...to diminish the power of blindness'. ${ }^{32}$ How history is told and whose story is told is essential to his project, as well as to others such as Anthony Anghie. ${ }^{33}$ David Kennedy has sought to advocate for those narratives that highlight the 'the dynamics of power and hierarchy'. ${ }^{34}$ Other scholarship has chosen to see recent theories such as international constitutionalism, pluralism etc. as narratives so as to demonstrate how they let us see the same object of law in different ways - that each foregrounds different actors, institutions and visions. ${ }^{35}$ Each of these critical projects are concerned with reflexivity in relation to the substance of their claims - indeed they draw their strength from this: ${ }^{36}$ critical value is attached to narratives depending on which narrative is told, concern is attached to which worlds we see when different narratives are applied to it, whilst all the while being aware of the contingency of the positions taken.

My concern with narrative and narrative analysis differs. I focus on form, namely the form of legal theory as narrative and the content of this form. How is the narrative produced? What choices, assumptions, allegiances have been made? What cultural biases inform them? How does the narrative craft the legal world - present and future - into an object of desire? Each of these questions can be turned on the three critical projects just outlined, they can be turned on this article - and ought to be. The reflexive posture ought to be applied to itself. ${ }^{37}$ These are the reflexive considerations that animate my reading of d'Aspremont's texts.

The remainder of the article will consider some of the aesthetic and epistemological choices made by d'Aspremont and how these structure various parts of his text, the intellectual and social conditions in which these were made, as well as the ideology that emerges from his final thesis. Part II will consider the role that coherence plays as an aesthetic choice, as well as a substantive cultural preference for law and the construction of ideas. It questions whether this results in a form of hegemony and a specific form of necessity. Part III looks at the value of an absent adversary for d'Aspremont's text and how disciplinary debates

${ }^{2}$ M Koskenniemi, 'Histories of International Law: Dealing with Eurocentrism', (20 I I) I9 Rechtsgeschichte I 52, I 76.

33 A Anghie, Imperialism, Sovereignty and the Making of International Law (CUP 2005).

34 D Kennedy, 'The Political Economy of the World', (2013) 26 LJIL 7, 23.

35 L Lixinski, 'Narratives of the International Legal Order and Why They Matter: An Introduction', (2013) I Erasmus Law Review 2-5.

${ }^{36} \mathrm{P}$ Sloterdijk, Critique of Cynical Reason (M Eldred (tr.), University of Minnesota Press, London, Minneapolis I 987) 5-6.

37 Contemporary critical international legal thinking has avoided the self-reflexive manoeuvre. That is to say it has avoided questioning the context and nature of its own reflexive inquiry. See S Singh, 'Positivism and New Approaches to International Law' in d'Aspremont and Kammerhofer, International Legal Positivism in a Post-Modern World, Chapter I2. Indeed, the critical manoeuvres outlined presume their own notion of epistemological progress, where this 'consists in the construction and reconstruction of more adequate narratives and forms of narrative and epistemological crises are occasions for such reconstruction.' But such projects are problematic, as shown by A MacIntyre, 'Epistemological Crises, Dramatic Narrative, and the Philosophy of Science’ in A MacIntyre, The Tasks of Philosophy: Selected Essays Volume I (CUP 2006) 3, 6-8. 
and considerations not addressed in the text contribute to its importance, value and meaning. Finally, Part IV looks at the form of d'Aspremont's Hartian conceptual apparatus - how it is held together, the points at which it may or may not indicate its own impossibility and its ideological consequences.

\section{A Pathological 'Desire' for Coherence}

Coherence, today, 'tends to stand for pretense, untenable claims of knowledge and authority, and the unacceptable exercise of power. ${ }^{38}$ Despite its apparent decline in certain intellectual circles, coherence maintains a close and persistent relationship with how we think about and practice law. Here, it is understood as the willingness to flatten contradictions, or discard conflicts, in order to privilege and bring out similarities and regularities. ${ }^{39}$ It is intimately linked to the different notions of consistency, determinacy and order. ${ }^{40}$ These ideas are appropriated, and relied upon, as the need to make law coherent is part and parcel of the 'drive to rationalize' ${ }^{4 \mathrm{I}}$ They function as part of a common epistemology that has been a powerful force in modern Western philosophy..$^{42}$ Coherence is so encultured that it has structured jurisprudential thinking on legal reasoning from Hart to Dworkin, ${ }^{43}$ possibly been the foundations for most Anglo-American normative legal thought, ${ }^{44}$ has buttressed the liberal ideal of law's systemic function in political society ${ }^{45}$ and has strongly influenced the practice of international law in a time of fragmentation. ${ }^{46}$

The prevalence of and desire for coherence in international legal thought and practice is unremarkable. However, less so is that it functions as a symbol, or image, certainly an association, for progress, and the

$3^{8}$ Y Ezrahi, The Descent of Icarus: Science and the Transformation of Contemporary Democracy (Harvard University Press I 990), 283-284 ('Incoherence, by contrast, seems to indicate humility, a refusal to suppress subjectivity and diversity, the toleration of numerous notions of purpose, causation and reality.')

39 M Prost, The Concept of Unity in Public International Law (Hart, Oxford 2012), I 55.

$4 \circ$ Schlag, The Enchantment of Reason, 6-7; P Schlag, 'The Aesthetics of American Law', (2002) I 5 Harvard Law Review i 049, 1059.

$4^{\text {I }}$ Ibid, I 099 .

42 K Kress, 'Legal Reasoning and Coherence Theories: Dworkin's Right Thesis, Retroactivity, and the Linear Order of Decisions', (i 984) 72 California Law Review 369, 370.

43 Ibid; Kennedy, A Critique of Adjudication, 33-37.

44 P Schlag, 'Normativity and the Politics of Form', (I 99 I) I 39 University of Pennsylvania Law Review 80I; P Kahn, The Cultural Study of Law: Reconstructed Legal Scholarship (University of Chicago Press, Chicago r 999) 7-30 (critiquing the pathology of normative legal thinking in this regard).

45 Kennedy, A Critique of Adjudication, 23-38.

46 'Fragmentation of International Law: Difficulties Arising from the Diversification and Expansion of International Law', Report of the Study Group of the International Law Commission, Finalized by Martti Koskenniemi, A/CN.4/L.682, I 3 April 2006, paras. 22, 33-35, 487. For a critique of the Report's approach to coherence, see S Singh, 'The Potential of International Law: Fragmentation and Ethics', (201 I) 24 LJIL 23, 33-35. 
hegemonic manoeuvres this can induce. This is to say that coherence is desired - and this desire is pathological - but this desire is in fact a desire for progress. It is this that is infused, in various guises, throughout d'Aspremont's text. Coherence functions on a number of levels - epistemological, aesthetic and ethical. When suited and wished, it is a property presumed of the world, and at other points it is a property to be imposed upon and realised within the world. It is each of these images that emplots d'Aspremont's text in various ways and draws a certain kind of relationship between the concepts, images and aesthetics that he invokes. That reality is reduced is the very logic of formalism, for this is where the stringency of ever more formal rules requires a reductive approach to reality. At the same time, d'Aspremont seeks to build a theory that is sustained by appreciating 'practice'. The need to simultaneously reduce reality and appreciate its complexity is the tension that is mirrored throughout his text. Importantly, it is a tension denied; one that is all the more apparent when it is most stringently repressed.

\section{A. Coherence, Order and Necessity}

d'Aspremont argues that his renewal and resurrection of source formalism is urgently necessary. FSIL may reintroduce order at a time of disorder; it can answer questions that are existential to the discipline. The narrative, here, is emplotted by an almost pure romanticism: the disordered world we experience today may be overcome. ${ }^{47}$ This is argued in two moves.

First, d'Aspremont presents the reader with a world filled with disorder, both in international legal scholarship and in practice. Scholarly debates are 'cacophonic', not far 'from becoming a henhouse or a Tower of Babel' (34), occurring amongst 'a cluster of different scholarly communities' (3) that seemingly 'talk past each other' because each of them uses 'different criteria for the ascertainment of legal rules' (34). Coherence and order is still valued to remedy this in times of intellectual specialisation and fragmentation. ${ }^{4}{ }^{8}$ And yet, the inability to distinguish law from non-law, to determine what is law, is perhaps the greatest form of disorder. The rigorous ability to distinguish law from non-law in a complex world is becoming impossible ( $\mathrm{I}$ ). The concern is not only the proliferation of rules, but that their modes of production have 'undergone an intricate and multi-fold pluralization' (2). The formal sources currently employed have 'grown inappropriate to capture contemporary international norms' (3). What we see from

47 White, Metahistory, 8-9; N Frye, The Anatomy of Criticism: Four Essays (Princeton University Press I957), I 58-238; West, Jurisprudence as Narrative, I 50-I 5 I.

$4^{8} \mathrm{P}$ Allott, 'Law and Social Evolution: Post-Evolutionary Human Involution', ASIL-ESIL Workshop University of Cambridge Speech, 20-2I September 20I2; S Singh, 'Two Potential Paths Forward from Fragmentation Discourse: Sociology and Ethics', (20 I I) I05 ASIL Proc I 30. 
d'Aspremont is not merely discursive complexity but also that of international legal practice.

Second, d'Aspremont then situates this problem of disorder, and its corresponding ideal of order, as an existential issue within international law. Disorder, in both its guises, is not a trifling issue, but one that cuts to the core of our discipline. ${ }^{49}$ The following concerns are pressed, as ones of imminent necessity, onto the reader: if one cannot separate law from non-law how can the normative character - namely, law's ability to generate and effect change in the behaviour of its addressees - of international law survive? (30) If legal rules have no normativity how can international law retain its authority? (3 I-33) If international law lacks authority and normativity, separately and interdependently, is the discipline itself being sidelined? If identification of rules lies along some arbitrary normative 'continuum' (I) how can international law retain its disciplinary and discursive individuality from the grasp of international politics? If the conceptualization of norms is based on examining their effects - namely, 'whether and how subjects...come to accept those norms, rules and standards' ${ }^{\circ}$ - then are we not introducing a new natural law within the discipline? Is this not merely the guise under which political science becomes the grounding for research into international law?

FSIL's own necessity is found in how it foregrounds each of these questions. d'Aspremont confronts the reader with them and by the book's end ensures that this confrontation is indispensible. His answer is unambiguous and presented with great clarity: source formalism is the saviour of international law's normativity, authority and relevance. It can help sustain a disciplinary core. Deformalization is the enemy found in both practice and theory (II9-30). This drama is one that is cast through the counterpoints of disorder/order, threat/defence and disease/medicine - and these weave themselves throughout the text. But in each of these counterpoints, the move is from left to right; the story is about transcending disorder and achieving order. It is a story of triumph, made all the more important because, it is just that much more necessary at this historical juncture.

\section{B. Coherence, the Politics of Theory and Hegemony}

A large part of FSIL is dedicated to ordering various theories of international law and their relevance to theorising the sources of international

49 d'Aspremont does at one stage seem to recognise that one of the key topics considered within his book, that of determinacy, indeterminacy and disambiguation, is an 'existential question' that 'will abidingly continue to fuel scholarly debates' (I43). In my view this topic is only one of the existential issues addressed by d'Aspremont.

$5^{\circ}$ J. Klabbers, 'Law-making and Constitutionalism' in J. Klabbers, A. Peters, G. Ulfstein (eds.), The Constitutionalization of International Law (Oxford: OUP, 2009), 98. Quoted in d'Aspremont, (I22). 
law. It is a process that allows d'Aspremont to compartmentalise various theories, to adequately demarcate them, in order to sustain and guard the conceptual space for his Hartian source thesis. This is, in part, a conscious process, and simultaneously a process that d'Aspremont's text undergoes and unconsciously enacts. Coherence is the 'preliminary criterion' ${ }^{1}$ of this ordering. Here, coherence is to be understood as an aesthetic, and not only a substantive ethical predisposition of 'the good'. In this sense it 'pertains to the forms, images, tropes, perceptions, and sensibilities that help shape the creation, apprehension, and even identity of human endeavours, including, most topically, law., ${ }^{52}$ d'Aspremont's 'rejuvenation' (5) of source formalism is achieved as much by how this aesthetic functions throughout his text, as by virtue of the substance of his thesis. ${ }^{53}$ What I explore is how it reflects the marketing of an idea in parts of our discipline.

The first three substantive chapters of the book (Chapters 2-4) are concerned with precisely this demarcation strategy. FSIL begins by delineating the specific type of formalism the book is concerned with. This is not the formalism of legal argumentation, process-based law creation or State consent, but one of the ascertainment of legal rules according to formal yardsticks (12-25). These distinctions are welcome, but as will be seen it may be difficult for d'Aspremont to sustain his distinction between the formalism of sources, and that of what he terms substantive legal argumentation (see Part V.B. below). d'Aspremont then explores the extent to which a formalism regarding sources is explored in general legal theory and international legal theory. We are whisked from Austin and Bentham, to Kelsen and Hart, before resting on Twining and Tamanaha, within general jurisprudence (38-62). Even at this juncture, the book's focus is squarely on how social observational understandings of the source thesis have been refined and historically understood. Unfortunately, it all but ignores the ruptures and disagreements between these theorists. For instance, the sharp divide between Hart and Kelsen is all but sidelined as a coherent picture of the book's central thesis is painted. ${ }^{54}$

Demarcating the relevance or irrelevance of certain theories to one's own thesis can be achieved in a number of ways. d'Aspremont does not simply discard competing theories as irrelevant, i.e. the simple

5I M Foucault, The Order of Things: An Archaeology of the Human Sciences (Routledge, London 2005), xxi ('there is no similitude and no distinction, even for the wholly untrained perception, that is not the result of a precise operation and of the application of a preliminary criterion.')

52 Schlag, The Aesthetics of American Law, I 050.

53 Not only does the aesthetic foreground the substantive thesis, but the assertion of this aesthetic is a moment of power. The nature of this power is hard to identify because 'an aesthetic imposition... escapes determination by reason. It is the artistic, rhetorical, political moment par excellence. It is important to avoid romanticizing this moment. It may be a creative moment, but it is one with very high stakes, and it is not necessarily benign.' Ibid, I I I I, fn. 227.

54 See generally, J Beckett, 'The Hartian Tradition in International Law', (2008) I The Journal of Jurisprudence $5 \mathrm{I}$. 
mechanics of exclusion, but rather seeks to reconcile his own thesis with the tenets of competing theories. This process requires downplaying and subsuming the potential critiques of these other theories (217-220), rather than seeing conflict and competition between them. Where critiques of Hart are acknowledged, their significance is immediately bracketed. For example, the reader is introduced to Dworkin, but his critique of Hart's social thesis is not fully considered, let alone answered (88-90). Another example: 'New Legal Realism cannot be construed as a proper critique of formalism' (I05), even if its emphasis on socio-structural considerations within law would have a great deal to say about the limits of d'Aspremont's social thesis based formalism. The critique from Critical Legal Studies (CLS) is considered as being directed towards the 'discipline' ( I I 4), the 'legal consciousness of the profession' (93) and the formalism of legal argumentation (I I2-3). The acknowledgment that CLS has also 'delivered a fundamental critique of law-ascertainment models', (I I 5) and offered 'the most powerful [contemporary] critique' (I I) and not 'spared the social thesis' (I I6) are all emphatic statements deserving of greater attention. I do not contend that each of these need to be explored - this would be unenviable task. My concern is that conflict, discord and struggle are subsumed under the label of mere difference. This not only protects d'Aspremont's thesis from critique but also imports a sense that these theories can be easily and coherently compartmentalised. The aesthetic virtue of order, amongst (non-conflictual) plurality, is again prioritised. There is, however, an interminable tension that marks this process.

On the one hand, d'Aspremont can (and does in later work ${ }^{55}$ ) defend his disinterest in the details of various critiques by relying on the equivalent to Thomas Kuhn's methodological incommensurability thesis. This thesis argues that scientific theories 'see different things when they look from the same point in the same direction' ${ }^{56}$ that they exist in 'different worlds'. ${ }^{57}$ Certain theoretical approaches may be considered a priori incompatible with other theories. For Kuhn, 'evaluation across different conceptual schemata, ways of life, or cultures is impossible. ${ }^{{ }^{8}}$ To choose one theory is to necessarily forego the other - positivism/naturalism, idealism/realism etc.

However, had he so chosen d'Aspremont could have let us see these theories as commensurable. Perhaps because certain legal theories emerge from a common epistemology, or by appealing to common intellectual structures such as 'science', 'reason', 'realism', or even because

\footnotetext{
55 d'Aspremont, Reductionist Legal Positivism, 370; d'Aspremont, Wording, 596-599 (speaking of paradigms and paradigmic revolution).

${ }^{6}$ T. Kuhn, The Structure of Scientific Revolutions (Chicago University Press I970), I 50.

57 Ibid.

$5^{8}$ R Chang, 'Introduction' in R Chang (ed.), Incommensurability, Incomparability, and Practical Reason (Harvard University Press I 997) I-33, I.
} 
they belong to the same tradition. ${ }^{59}$ However, the intellectual progeny of Kuhn is preferred. This provides a strong immunity from critique, and imports a sense of the reasonable theorist - we can agree to disagree because we are talking about very different things and with very different world-viewpoints, even if we appear to be starting from the same point. It allows a theorist to cast aside as paradigmically different those theories that may pose the greatest critique. It is however based on a theory of knowledge of the hard sciences, and not of the social sciences. In FSIL, its application allows d'Aspremont to defend his resurrection of Hart against its strongest critics: Dworkin, New Legal Realism and CLS work with different conceptual schemata and visions of the world to Hart's social thesis. The methodological immunity from critique ought to be self-evident.

On the other hand however, d'Aspremont presents his thesis as having 'conciliatory virtues' (2 I7): 'it helps reconcile some allegedly antonymic trends in international legal scholarship' (2 I 8). To reconcile competing claims between theories presumes the possibility of a discursive relationship between theories. It presumes that two theories can communicate as well as a degree of understanding between them that is not inherently asymmetrical. It presumes commensurability between such theories. Here, in d'Aspremont's discourse of conciliation, methodological incommensurability can be avoided, theories can be reconciled, and the reasonable theorist, aware of competing arguments is capable of weaving between them.

There appears to be a conflict in how d'Aspremont's theory is positioned in relation to other theories. To only expose this methodological issue would be to miss how it functions as a narrative tactic to elevate d'Aspremont's thesis. I offer two interpretations of how this move is made.

It should be clear that Kuhnian incommensurability between theories depends upon there being a position where one can identify competing theories as incommensurable. It presumes a position where each theory can be understood - an independent point from which to compare these theories and identify their incommensurability. The first potential critique of d'Aspremont is not that he attempts to adopt conflicting starting points in how to view the relationship between legal theories (incommensurability and conciliation) but that he does not explore the consequences of adopting both together. This results in the sense that FSIL privileges order and discursive coherence, indeed this is imposed, over any substantial engagement with the greatest critics of his thesis, those with whom it finds contradiction and conflict. One is left with the feeling that a Kuhnian methodology is superficially and strategically

\footnotetext{
59 See generally, S Pepper, World Hypotheses: A Study in Evidence (University of California Press, Berkeley I 966), I4I et seq.; White, Metahistory, 23; A MacIntyre, After Virtue: A Study of Moral Theory (University of Notre Dame Press, Notre Dame, $3^{\text {rd }}$ edn. 2007), 204-225.
} 
deployed to bracket the fierce competition that one finds between ideas, and introduces the ideal of harmony amongst diversity. ${ }^{60}$ The strategies of marketing an idea, it seems, are still so characteristically liberal. ${ }^{61}$

There remains another possible interpretation of d'Aspremont's methodological manoeuvrings. It is premised on appropriating the effects of intellectual and theoretical specialisation, alongside the functioning of hegemony within international legal scholarship. d'Aspremont's formalism is only concerned with the identification of rules; it is 'modest'. ${ }^{62}$ This narrow and particular claim allows d'Aspremont to assert that other legal theories may and can 'explain the whole phenomenon of law'. ${ }^{6}$ FSIL's formalism, because of its modesty, and claim to be solely concerned with the identification of norms, can 'underpin the continuously mutually enriching character of...multiple strands of contemporary international legal scholarship' (2 I8), because it is 'nonexclusive, non-confrontational and conciliatory' (219). The author presumes that his approach to theory can promote 'ecumenism' ${ }^{64}$ or unity within international legal scholarship. Whilst d'Aspremont seems, again, to elevate a peaceful coherent vision of international legal scholarship, there may be other motives.

Underpinning d'Aspremont's argument is first the assertion that unity across international legal scholarship can be achieved if its arena can be carved up into different component parts (different areas of enquiry) that may be governed by different theories. d'Aspremont neo-formalism can govern the identification of rules, by outlining a theory on the sources of international law; constructivists and international legal realists can examine international law as a social and material construct, and may critique the application of legal rules; and so on. This allows d'Aspremont to cast aside competing theories. ${ }^{6}$ It is an approach that reduces legal theories to works of theoretical specialisation that only relate to very narrow and different jurisprudential enquiries. Coherence is imposed on the field with the aid of such presumed and stringent specialisation. Legal theories are compartmentalised and potential conflicts are eschewed. However, this is a position that of course cannot embrace conciliatory unity through discussion between theories, or even a measure of Kuhnian incommensurability (because you are not looking from the same point to start with, but rather start off with very different enquiries).

It is doubtful that these theories can be carved up in this manner, or that the conceptual apparatuses used to examine the application and

60 Later writings do little to assuage this concern. See d'Aspremont, Reductionist Legal Positivism', 369 .

${ }_{\text {6I }}$ The idea of finding order amongst pluralism and fragmentation is a dominant concern in late modernity and postmodernity, as well as political liberalism and neo-liberalism. See e.g. D Harvey,

The Condition of Postmodernity (Blackwell, Oxford r990), 5-9.

${ }^{6}$ d'Aspremont, Reductionist Legal Positivism, 370.

63 Ibid.

64 Ibid.

65 See further Singh, Positivism and New Approaches to International Law. 
identification of legal rules, can be so easily separated. More importantly, reality itself cannot be carved up in this manner. Theory itself cannot be so non-confrontational when it is concerned with a Hartian thesis that has been persistently challenged for the last fifty years. It especially cannot be so when laying claim to international law's form. If the sources of international law are the gateway to legality, normative claims as to how formal they ought to be cannot be innocent and non-confrontational. When one considers each of these concerns together, it is difficult to not conceive of d'Aspremont's neo-formalism as seeking a theoretical monopoly on international law's key: its sources. The 'responsibility assigned to [my project] remains, in my view, of primary importance. ${ }^{66}$ d'Aspremont's ordering of the discursive field is the imposition of a 'false unity ${ }^{67}$ behind which, in all likelihood, lies a hegemonic manoeuvre garbed in conciliatory clothing.

\section{Coherence, Eternal Return and False Progress}

By now it should be relatively clear that it is not so much the pathological desire for coherence that structures d'Aspremont's text. Coherence is a symptom or image for progress seen as order. We have seen how this plays out as a romantic drama in d'Aspremont's treatment of international legal scholarship. It is also found in the substance of d'Aspremont's thesis which will be detailed and critiqued in section IV. Unsurprisingly it lies at the heart of d'Aspremont's Hartian social thesis: sufficient uniform and communitarian coherence exists in the practice of law applying authorities to determine increasingly formal standards for the rules relating to the sources of international law. In contrast to d'Aspremont's romantic emplotment (which relies on disorder as a starting point), reality is now, in his substantive argument, seen as sufficiently coherent, without conflict or contradictions, to give rise to more formal sources rules - it is presupposed rather than imposed. There is now no need for triumph. But for d'Aspremont there is a need to make law more determinate, indeed this must be imposed, if international law is to confront its challenges. Less indeterminate sources lead to a more determinate and coherent international legal order. The focus of d'Aspremont's romantic drive has shifted: it is now for a coherent legal system, understood as a set of rules, not for a coherent social world. But greater determinacy, greater clarity, and greater coherence are the prerequisites of progress for the discipline at this historical juncture.

Of course, this argument is not new. Rather, it bears all the hallmarks of inter-war discourse in international law. ${ }^{68}$ The formalist's, and

${ }^{66}$ Ibid (emphasis added).

67 Foucault, The Archaeology of Knowledge, 38.

68 Koskenniemi, The Gentle Civilizer, 266-352; S Astorino, 'The Impact of Sociological Jurisprudence on International Law in the Interwar Period', (I996) 34 Duquesne Law Review 
d'Aspremont's desire for greater determinacy is dogmatic in the sense that it is willing to impose this upon, whilst claiming to "find" it within, reality. It is willing to cast aside the contradictions and conflicts found in reality. This is the pathology of a formalist's coherence. During the inter-war period this mentality was required for renewal and rehabilitation within the discipline. Today it is required to confront the complexities of the world and the vagaries of theorizing (I-3). Coherence promises progress and transcendence. It is set to work in d'Aspremont's text as an almost entirely romantic emplotment. This, as Nietzsche well knew, was a false promise; it is the burden of eternal return. ${ }^{69}$ From Jhering and Heck, to the Scandinavian legal realists, and some American legal realists, we see the same willingness to squeeze the social into the formal in order to argue that the sources of law have been discerned. The worry is that the 'disciplinary hamster wheel' 70 continues to spin unbounded. Not only is this functioning of structure hidden from d'Aspremont's narrative (i.e. the reflexive move is not considered), but it is accompanied by promises that are unlikely to be fulfilled.

This critique, to the extent that it is the natural counterpoint to d'Aspremont's logic of coherence, is also just another rotation on the same wheel. Coherence, for d'Aspremont's text, is both an aesthetic and a substantive ethical predisposition; it functions as a symbol and image for a progress that will not come. It provide the initial pleasure, and ultimate discontent, of myths:

Myth does not deny things, on the contrary, its function is to talk about them; simply its purifies them, it makes them innocent, it gives them a natural and eternal justification ... myth acts economically: it abolishes the complexity from human acts, its gives them the simplicity of their essences, it does away with all dialectics, with any going back beyond what is immediately visible, it organizes the world which is without contradictions because it is without depth, a world wide open and wallowing in the evident, it establishes a blissful clarity ... ${ }^{71}$

\section{Saving the Discipline: Conquering an Absent Adversary}

FSIL's adversary is deformalization, in its various guises (II9-I36). d'Aspremont's romantic emplotment requires that this adversary be confronted and overcome. But d'Aspremont accompanies this with an effort to divulge the politics and biases of his formalism (I37-I47) and

277; T Skouteris, The Notion of Progress in International Law Discourse (TMC Asser Press, The Hague 20I0), Chapter 3.

69 F Nietzsche, The Gay Science (B Williams (ed.), J Nauckhoff (tr.), CUP 2008), I94-I95, section 34I (outlining the condition of thinking for an ever-returning way of thinking).

70 D Kennedy, 'When Renewal Repeats: Thinking Against the Box', (2000) 32 New York University Fournal of International Law and Politics 335, 407.

${ }^{71}$ R Barthes, Mythologies (A Levers (tr.), The Noonday Press, New York I972), I 43. 
deformalization (I30-136). The effort to expose the politics of a discourse is to an extent the limited result of postmodern intellectual movements, but it is also a method appropriated by traditional normative legal theories. What I mean by this is that to expose the politics of one's position, and of one's adversary, is to be able to demonstrate that legal theory can be transparent about motives, can exist in a certain pluralism and that a reader or theorist can make a neutral choice about which position she may prefer. ${ }^{72}$ In this liberal co-option of the postmodern posture, the reader is left with the image that she is fully informed of the substantive positions of different theories and what lies behind these positions (their politics and motives), and so can make an autonomous choice between positions. The preservation of rational and autonomous choice is key for the liberal legal theorist. ${ }^{73}$

d'Aspremont presents the reader with a choice between the politics of deformalization and the politics of formalism. That is, a preference for the self-serving quest to expand international law's normative reach and stretching the discipline's frontiers ( $130-\mathrm{I} 34$ ), or for the preservation of international law's normative character and therefore its authority, legitimacy and efficacy (145). The second choice presented is between accepting indeterminacy or striving 'to disambiguate legal rules' (I42). Several important questions emerge: are these really free, autonomous choices that a legal theorist can make? What are the true politics of deformalization: how has d'Aspremont's constructed his adversary and is this sufficient? Will making the 'right' choices (formalism and relative determinacy) really save the discipline?

I argue that d'Aspremont's FSIL does not fully explore the depths of the politics at play behind the resurgence of formalism; that these concerns lie dormant in his text and more emphatically emerge from the discipline's 'associated field'. The move to formalism is about disciplinary colonization and empire. Saving the discipline, as d'Aspremont's comic romance seeks to do, ${ }^{74}$ is about realising that there is no escape from this disciplinary drama.

d'Aspremont understands that international law is constituted by 'battle[s] within the profession' and 'battle[s] among professions'. In this sense he understands the relevance of Foucault (I33). He understands that disciplines are social constructs, subject to the direction and whimsy of its participants - though of course not any whimsical direction is open to them. A discipline's continuity and evolution depends, like all traditions, on the sustainability of a core set of beliefs, rules or 'entrenched ideas' $^{75}$ But it is also constituted by continuous conflict over

72 d'Aspremont talks about choices in FSIL, Chapter 6 and Reductionist Legal Positivism.

73 P Schlag, 'The Empty Circles of Liberal Justification', ( I 997) 96 Michigan Law Review I, I 9.

74 White, Metahistory, 9 (providing a definition of comedy in narrative).

75 Crawford, International Law as a Discipline and Profession, 476 ('the system is ordered such that entrenched ideas are unlikely to succumb, as distinct from being modified through practice or the accretion of new ideas and values'). 
interpretations of its identity, its limit and its potential. Epistemic disagreements are key to the discipline's sustenance, renewal and fortitude. But it is only where such disagreements destabilise the core beliefs or rules of a discipline that it risks descending into incoherence and rupture. In approaching the issue of deformalization and the need to save the discipline, two questions need to be asked: (a) is international law such a discipline that operates around a core set of beliefs, rules or 'entrenched ideas'? If so, (b) does deformalization as presented by d'Aspremont threaten to disrupt such core beliefs or rules?

Before these questions are addressed, what does d'Aspremont mean by his concept of deformalization? He asserts that to devise a sources theory based on moral or ethical criteria ( I I9), or on the effectiveness of norms (I22), or on an understanding of law as process (I27), is to embrace deformalization. He focuses on the second and third of these $(4,29$, I05-I IO, I22-I28). These various understandings have 'led to the existence of a grey area where it is not possible to distinguish law from nonlaw' ( 128 ). He rightly draws attention to disciplinary motives for such deformalization: the construction of new rules, promoting the expansion of international law, a self-serving quest for new legal materials, and fulfilling an authority deficit (I30-I34). I argue, however, that d'Aspremont does not push his analysis far enough. His conceptual analysis of deformalization is thorough, but he does not fully explore the consequences, ideational and material, of such a concern within international law. Formalism has been resurgent as a European posture in response to empire, instrumentalism, disciplinary colonization and the threat of 'extinction' ${ }^{\prime 6}$ of the discipline. d'Aspremont has subsequently sought to relate the politics of his formalism to this wider disciplinary political drama. ${ }^{77}$ The significance of FSIL cannot be divorced from the wider European posture found in international law's discursive field; these are the determinate conditions in which the book was produced and is read.

FSIL rightly takes issue with compliance being used as a yardstick for the ascertainment of international legal rules (I22). d'Aspremont rallies against the following effects-based understanding of law-ascertainment (I22, footnote 28 ):

Once it is recognized that law's existence is best measured by the influence it exerts, and not by formal tests of validity rooted in normative hierarchies, international lawyers can finally eschew the preoccupation with legal pedigree (sources) that has constrained creative thinking within the discipline for generations. ${ }^{78}$

76 Ibid, 485 .

77 J d'Aspremont and J Kammerhofer, 'Introduction' in Kammerhofer and d'Aspremont, International Legal Positivism in a Postmodern World.

${ }^{8} \mathrm{~J}$ Brunnée and S Toope, 'International Law and Constructivism, Elements of an International Theory of International Law', (2000) 39 Columbia Journal of Transnational Law I 9, 65. 
Whilst this is the statement of self-confessed constructivist scholars within the field of international relations, a number of legal scholars (notably American) have sought to identify what is law by its effectiveness and compliance. ${ }^{79}$ The formal logic of law is reduced to economic functionality: in 'economic terms, law is relevant to the extent that it generates a marginal increase in compliance. ${ }^{80}$ The use of rational choice theory by American international legal scholars collapses a distinction that has long been cherished by European jurisprudence: what the law is, is a different inquiry to whether it is effective or not. Rational choice theory assumes self-interest as a determining directive, rather than an analytical tool. 'International law emerges from states' pursuit of self-interested policies on the international stage... It is not a check on self-interest, it's a product of self-interest. ${ }^{8 \mathrm{I}}$ Rational choice law and economics theorists do not simply provide another angle of observation. In recent European scholarship it has been received as a project of disciplinary colonization and one that buttresses American empire, in which deformalization is but one move. ${ }^{82}$ The moves may be considered as follows.

First, the interdisciplinarity introduced by rational choice law and economics is one that formalises international law. It simplifies the complexity of international legal rules and their functioning. ${ }^{83}$ It formalises to the extent that it requires international law to be simpler and more determinate than it actually is. This is a methodological necessity to the extent that such law and economics theorist need a static, simplified and formal object whose effectiveness can be measured. Its methodology requires concrete, measurable and verifiable considerations; it is premised on a series of empirical claims that are often vaunted as 'objective'. It seeks to harness an ideational power possibly more forceful than that of law, that of 'science'. ${ }^{84}$

Second, just as law and economics scholarship can formalise to the point of absurd simplification, it just as willingly deformalizes. This deformalization manifests itself in distinct senses of the concept. At the most abstract level, rational choice law and economics theorists

79 See most recently, E Posner and A Sykes, Economic Foundations of International Law (Harvard University Press 20I3).

80 A Guzman, How International Law Works: A Rational Choice Theory (OUP, New York 2008), 22-23.

${ }^{8} \mathrm{I}$ J Goldsmith and E Posner, The Limits of International Law (OUP, New York 2005), I3; see also, E Posner, 'Do States have a Moral Obligation to Comply with International Law?', (2003) 55 Stanford Law Review I 90 I; E Posner, The Perils of Global Legalism (University of Chicago Press, Chicago 2009), ix, xv.

82 Klabbers, The Relative Autonomy of International Law or the Forgotten Politics of Interdisciplinarity, 36; Koskenniemi, The Gentle Civilizer, 489; M Koskenniemi, 'Law, Teleology and International Relations: An Essay in Counterdisciplinarity', (2012) 26 International Relations 3, i 8 .

83 Klabbers, The Relative Autonomy of International Law or the Forgotten Politics of Interdisciplinarity, 36-38; Crawford, International Law as a Discipline and Profession, 482-484.

${ }^{84}$ M Foucault, 'Two Lectures' in M Foucault, Power/Knowledge: Selected Interviews and Other Writings $1972-77$ (C Gordon (ed.), Pantheon, New York I980) 78, 85 
remove or marginalize the need to ask the legal question. These scholars prioritise the approach to international law with a deontological question of its effectiveness and compliance. This is necessarily a question that cannot be answered by recourse to a legal rationality or method - the relevant method is the empiricism of economics or political science.

Third, on a less abstract level, such scholars consider irrelevant the distinction between different international legal sources. If form is to be found in the sources of international law, as d'Aspremont contends, then this is a certainly a form of deformalization. It is irrelevant to consider whether one is concerned with soft law or accepted legal rules, standard or stringently formal rules; what matters is which norms, irrespective of source pedigree, influence state behaviour. ${ }^{85}$ The concern of whether a norm is a rule of the international legal system is considered irrelevant; what makes a rule specifically legal is discarded as an irrelevant inquiry.

Fourth, as can be seen in Brunnée and Toope's remark, the effectiveness of a international norm conditions whether it may be considered a legal rule. What is considered legal requires first answering a non-legal question. Law is no longer a closed-off, self-validating system, but rather one that bows to the logic of political scientific determinations. Academic conquest cannot be more subversive than this. What is governed, by a non-formal and hence non-legal rationality, is arguably the master signifier for international law: its sources. The actor whose conceptual apparatus is able to determine a discourse's master signifier is able to control its direction and content. In turn, this suggests that international law's autonomy is impossible.

If left here, the debate remains purely ideational; what we have is the conceptual framework of rational choice law and economics theorists and the process by which this framework deformalizes. But this would be to miss the debate's essential connection to power, more specifically, the material dimensions of power. This concern emerges in two senses.

The first is the role that rational choice law and economics theorists play in subjugating the field of international law and their role in redistributing the allocation of disciplinary power. ${ }^{86}$ In 2005, Goldsmith and Posner remarked that there is a more sophisticated international law literature in the international relations subfield of political science. ${ }^{87}$ For some European scholars, it is concerned with becoming the new international law. ${ }^{88}$ But this charge towards disciplinary dominance is driven and sustained by law and economics' robust and expanding material base. Here rational choice law and economics is no longer seen as just a theory - a conceptual apparatus with conceptual

85 Guzman, How International Law Works, 9, I42-I47.

86 Klabbers, The Bridge Crack'd, I 20.

87 Goldsmith and Posner, The Limits of International Law, I5.

88 Koskenniemi, Counterdisciplinarity, I 8. 
consequences - but a project. Its institutional moorings, and theorists, have expanded well beyond its birthplace at the University of Chicago. Funding bodies such as the Ohlin Foundation has ensured that institutes for law and economics exist through the US. Those that subscribe to it, have introduced the theory into judicial decision-making - most notably Richard Posner. The material reach of the law and economics project extends well beyond the shores of the US, but it is there that it has become engrained. To recognise that the school has particular sociopolitical ambitions is to realise that its continued expansion may shift and govern various parts of the international legal discipline.

The second relationship to power is how such projects support and enable empire. ${ }^{89}$ Koskenniemi has lamented the manner in which both liberal and neo-liberal American international legal scholarship has provided the basis for empire. ${ }^{90}$ Crawford is concerned 'that much that passes for the study of international law in the United States academy is at best the foreign relations law of the United States with ideological interpolations. ${ }^{91}$ Deformalization and the conceptual consequences of the law and economics movement are not only ideas that can compete with each, but rather ones that may influence and support the practice of international law and international relations in the United States. Such ideas 'cannot but buttress the justifications for American empire'.$^{92}$

The reasons why d'Aspremont's approach to deformalization is problematic ought now to be clearer. His overarching narrative is premised on not only overcoming deformalization, in its various guises, as an adversary, but also on allowing the reader to make a free autonomous choice between competing projects (deformalization/formalism and indeterminacy/relative determinacy) by exposing their politics. d'Aspremont, however, does not fully explore the nature of his adversary or the full conceptual consequences of deformalization. I have attempted to look at some of these discursive disciplinary consequences. But deformalization ought also to be understood as a concept with specific relationships to power. The choice required of the reader cannot be made without these additional considerations. The choice that one is making is not merely between different theoretical or conceptual strategies, but between competing material projects with particular socio-political ambitions. Given deformalization's relationships to power, the value given to such a choice may be greatly overestimated; what can be legitimately achieved by 'choosing' formalism may be very little indeed. d'Aspremont's narrative, to the extent it views deformalization as an adversary, is now not so much structured by the tropes of a romantic comedy, as it is by tragedy. ${ }^{93}$

${ }^{89}$ See generally, J Ohlin, The Assault on International Law (OUP, $20 \mathrm{I} 4$ forthcoming).

$9 \circ$ See Koskenniemi, The Gentle Civilizer; Koskenniemi, Counterdisciplinarity.

91 Crawford, International Law as a Discipline and a Profession, 484.

${ }_{92}$ Koskenniemi, The Gentle Civilizer, 484.

93 White, Metahistory, 9 (defining tragedy as a narrative concept).. 
To think that the discipline can be saved in the manner that d'Aspremont advocates may be misguided, but perhaps more so is the belief that it needs to be. ${ }^{94}$ Of course deformalization places into question certain core beliefs or rules of the discipline: it removes international law's capability to autonomously determine what is legal or illegal so it is no longer a self-validating or closed-system procedure, and it does away with the sources doctrines. Even though d'Aspremont does not fully explore these consequences or the reasons for them, they represent a deep disagreement about the discipline's identity. And yet they are unlikely to destabilise it in any considerable way. This is not because international law may always rely on other entrenched ideas, but because deformalization is a known argumentative trope within the discipline. Alongside formalism, deformalization has long appeared as part of the drama of governance within the discipline. Modern manifestations are no more than a variation on a theme. At a conceptual level the discipline cannot be threatened with incoherence and rupture by ideas and argumentative strategies that it has long internalized. If there has to be any 'core' for the discipline it is not the myth of unshakable foundations or core concepts. Rather, a discipline functions and evolves through its reliance on tensions and conflicts. An appreciation of the inherent tension found in both the determinacy-indeterminacy and formalism-deformalization axes allows us to acknowledge that conflicting, and at times contradictory, positions comprise 'an intrinsic element [of] the discipline's identity and unity.'95 The discipline's resilience lies in how it internalises conflicting claims over its identity.

The choices given to the reader, between relative determinacy and formalism or indeterminacy and deformalization, would seem to be misleading. Neither, alone, is adequate for d'Aspremont's romantic emplotment. The reader is given a choice already conditioned and within the structure of the international legal discipline, the conflictual and contradictory structure that it is. ${ }^{96}$ To elide such structure and its constraint on choice is the very function of any ideological text. If the reader is to make a choice, it ought to be done in the full knowledge that she is still within the known tropes of the discipline. In short, choices are not always as autonomous as often presumed.

\section{The Thesis: Order, Determinacy and the Ideologies of Method}

I have argued that FSIL's narrative is structured around two pivots: coherence and an adversary. These induce a specific set of relationships

94 This critique can be found in other accounts, see e.g. Crawford, International Law as a Discipline and a Profession.

95 Prost, The Concept of Unity in Public International Law, I 55.

${ }^{6}$ Foucault, The Archaeology of Knowledge, 38-39. 
between various elements of d'Aspremont's text. Indeed, they attach themselves to specific concepts. Recall the relationship between coherence and order, necessity, discursive unity and progress, or deformalization's relationship to choice and disciplinarity. These pivots also work through the text on an emotional level: coherence and order seduces the reader into thinking that there may be a correct or right legal decision and that legal theories can exist in harmony, whilst deformalization relies on fear and the ultimate provision of hope. But these pivots, concepts, aesthetics and emotions can also highlight that there is something else going on within the text and outside of it. It is with these considerations in mind that we arrive at the content of d'Aspremont's Hartian thesis.

This section will first outline the thesis and look at how it has developed in relation to d'Aspremont's work on post-modern positivism (A). It then conceptually deconstructs d'Aspremont's Hartian approach to determinacy (B) and the ideological tenets of his social thesis (C). I look at how formalism's dependence on determinacy constructs a series of relationship with other concepts such as indeterminacy and normative authority, whilst also importing a specific theory of language. What emerges is a legal theory that is constantly self-referential, persistently trying (and often failing) to exclude precisely the sort of inquiries that may disrupt its logic.

\section{A. d'Aspremont's Formalism: a Description}

In FSIL d'Aspremont states that his book 'falls short of supporting legal positivism as a whole' (26) and that his call for greater source formalism cannot be conflated with a plea for legal positivism (8). However, since the publication of this monograph, he has advocated for and developed a project around a post-modern international legal positivism ('ILP') as a contemporary enterprise. ${ }^{97}$ There remain questions over the extent to which such a project is post-modern, and can survive the persistent conflicts found between the works of its authors, that is between a Hartian and Kelsenian jurisprudential approach. Here, I consider that there are some inconsistencies between d'Aspremont's formalism in FSIL and his later work on ILP. To be clear, however, source formalism remains at the masthead of both projects.

This narrow neo-positivist position stands for the following proposition: the validity of an international legal norm is determined solely by its pedigree, namely, its conformity with the legal system's sources. This is the 'source thesis'. This basic proposition is complemented by two others. First, the source thesis must ensure that the sources themselves

97 d'Aspremont and Kammerhofer, International Legal Positivism in a Post-Modern World. See also J Kammerhofer, Uncertainty in International Law: A Kelsenian Perspective (Routledge, London 20I0); J Kammerhofer, 'A Pure Theory of Law and its "Modern" Positivism: International Legal Uses for Scholarship’, (2012) Io6 ASIL Proc 365. 
are formal enough (I48) and second, the 'formal source thesis' is given meaning and capable of being determined through the social practice of law-applying authorities. This latter is a variant of Hart's 'social thesis'. Each is explored in turn.

The sources of international law ought to be stringently formal so as to reduce indeterminacy. The formal source thesis requires one to reject the argument that international law's sources are enshrined in Article 38 of the ICJ Statute (I49-50). d'Aspremont critiques those sources not based on the written word, for they do not possess the required degree of formality (I74). This critique extends to customary international law, the general principles of law and oral promises made by States. These sources, d'Aspremont argues, have been 'relentlessly cloaked... with a veil of formalism' ( I 5). For d'Aspremont, this collapses the distinctions between discrete intellectual processes: notably between the making of and evidence for a legal rule, and between determining the content of and ascertaining the existence of legal rules ( I 5 I ). These 'mirages of formalism that shroud the traditional theory of sources and which have allowed legal scholarship to live in an illusion of relative certainty regarding the identification of international legal rules' ought to be exposed and discarded (I 50). But if the indeterminacy and lack of formality in these sources is exposed, one is left with making the sources of international law formal enough to meet the standards of the formal source thesis. Here, for d'Aspremont, only those sources expressed in the written word are formal enough to ascertain the existence of legal rules (i78). d'Aspremont's formal source thesis is a normative project; it makes claims upon how the law of sources ought to be. This barrier to or requirement of formality functions to counter those approaches that are likely to deformalize. For example, sources cannot be dependent on the 'intent of the authors' (I79), unless said intent is translated into graspable material and linguistic indicators ( 182 ). Customary international law and other non-written sources only entrench and proliferate uncertainty and indeterminacy within international law. ${ }^{98}$ '[O]nly the systemic use of written linguistic indicators can ensure formal law-ascertainment in international law' ( 186 ).

d'Aspremont is also only concerned with formality in relation to the ascertainment of legal norms, and not their creation, content etc. He understands that 'both the content [of the norm] and the container [written instrument, treaty etc.] can potentially serve as a formal signpost that indicates whether the norm in question is an international legal rule' (I75, original emphasis). But for d'Aspremont formality in the ascertainment of legal rules lies with 'the container (instrumentum) of the rule' (I78).

$9^{8} \mathrm{~J}$ d'Aspremont, 'International Customary Investment Law: Story of a Paradox' in E Brabandere and T Gazzini (eds.), Sources of Transnational Investment Law (Martinus Nijhoff, The Hague 20I2) (making this argument). 
It is here that 'a distinction between law and non-law must be sought' ( I 78).

This formal source thesis is made to seem necessary by first exposing the indeterminacy that runs through both written and non-written sources. FSIL rails against some of the veils that are induced by formalism, and in doing so takes up the mantel of the legal realist. d'Aspremont then seeks to stem indeterminacy through the normative claims of his formalism. This argumentative pattern paints indeterminacy as that which must be cured, or at least a symptom to be treated or 'limited' ( 148 ), and formalism as the medicine.

But d'Aspremont also understands that his 'formal sources thesis' cannot go far enough in stemming indeterminacy: 'formalism in lawascertainment... is not self-sufficient... [because it] is shaped through ordinary language, [and therefore remains] inextricably beset by the indeterminacy of language if it were not grounded in the social practice of those applying it.' (I93) The formal source thesis, because of d'Aspremont's normative project, requires the social thesis. This stands for the following proposition: the meaning of sources is derived from the social practice of identified law-applying authorities within international law (5I-53). The social thesis presumes a specific theory of language, requires a method for identifying relevant law-applying authorities, and a method to ascertain the Hartian internal point of view (itself a social fact). ${ }^{99}$ These requirements are fulfilled as the reader is, respectively, thrown into Wittgenstein, Hart and Tamanaha, and finally an insufficient account of an abstract 'feeling'. These are the intellectual tenets of d'Aspremont's ultimately conservative theory.

Wittgenstein is invoked for the proposition that 'it is how the word is used that will teach us the meaning of the word' (I 99). The meaning of words is premised on a communitarian approach to their use. Consensus and convergence in the practice of language offers and determines meaning (196-200). d'Aspremont states that this does not require absolute agreement in the use of a word within an a set of law-applying bodies; complete agreement is 'probably elusive' (20I). The meaning of formal sources may be determined with this theory of language. For d'Aspremont the meaning of formal sources are determined by 'a shared feeling of [law-applying authorities] applying the same criteria' (201-202, original emphasis).

Tamanaha is then used to remedy Hart's methodological insufficiencies in order to answer the question of who are the relevant law-applying authorities in international law, who determine meaning ( $\mathrm{I} 7,203-204)$. For d'Aspremont, the relevant law-applying authorities are 'whomever, as a matter of social practice, members of the group (including legal officials themselves) identify and treat as "legal" officials' (203). ${ }^{100}$

99 H Hart, The Concept of Law (OUP I 997), I I6- I 7.

roo Quoting, B Tamanaha, A General Furisprudence of Law and Society (OUP 200 I), I 42. 
This is an endlessly circular logic: the social practice of law-applying authorities determines who may be considered as law-applying authorities. These same authorities will then determine the meaning of international law's sources, as well as of those legal rules that determine who are relevant law-applying authorities. Apart from this self-enclosed logic, d'Aspremont leaves the reader with only tentative notions of who may be considered as relevant law-applying authorities, namely, judicial authorities (domestic and international law), the ICRC and the ILC.

Presuming that such law-applying authorities can be adequately defined, there must be sufficient convergence in their social practice. How this convergence is established is the next enquiry. d'Aspremont assures the reader that the international society... is in a position to produce sufficient communitarian semantics...[but] it seems more questionable whether the current configuration of the international legal society allows for the emergence of a sustainable feeling of convergence of the practices of law-ascertainment' (213, original emphasis). Without sufficient convergence, the social thesis becomes paralysed. But d'Aspremont ultimately lays the responsibility for such a measurement at the feet of an experiential approach to the international legal profession. There is the blurring of methodological lines: social scientific observation, premised on various forms of empiricism, must ultimately depend on the immeasurable and non-empirical ('feelings'). This is a prelude, however, to d'Aspremont's new normative project. He argues that the communitarian deficiency in the social consciousness of the international legal profession can only be remedied by rallying around a common project and common language (2 I 4$)$.

\section{B. The Ideology of Determinacy}

d'Aspremont's FSIL is a recent rendition in the international legal discipline's desire to bring closure to the determinacy-indeterminacy debate, a debate excessive in its hubris, and more importantly, completely unnecessary. FSIL is a project of 'disambiguation' (I43); the formal source and social theses are each aimed at making international law more determinate ( 148 , I 93). The indeterminacy of formal law-ascertainment criteria 'is more restricted than what is often asserted' (I4I). And, of course, the 'international legal order provides at the least the possibility of a significant social practice which helps stem the indeterminacy of law-ascertainment mechanisms that is perpetuated by formalism itself.' (I 4I). Such academic musings, often in the form of normative international legal scholarship, feel an ethical imperative to either cultivate indeterminacy and/or impose determinacy. This stands true for jurisprudential schools ranging from Hart and Dworkin to CLS, realism, law and economics etc. Working along the axis of this argumentative trope can bring about new possibilities for international law's normative 
power, its legitimacy and its authority, or so go such narratives. However, such positions and debates are marked by an arbitrary and often untenable dichotomy - between relative determinacy and indeterminacy (e.g. I 42). Before making this argument, I will first clarify the different meanings that indeterminacy and determinacy may take.

\section{The Nature of Indeterminacy}

The need for clarification arises from my reading of FSIL's Chapters 4, 6 and 8, as well as of d'Aspremont's neo-positivist project. ${ }^{\text {Ior }}$ Upon reading these works, one can be forgiven for thinking that the indeterminacy confronted by d'Aspremont is not identical to the strain advanced by aspects of CLS, and consequently conclude that his approach is post-modern. This is not the case: the willingness to make sources more determinate is a method by which to stem structural indeterminacy. Given the attention that indeterminacy has received in jurisprudential debates, it is remarkable that its various manifestations have not been differentiated. To what object does indeterminacy attach legal concepts, rules, discourses, words, arguments or principles? What type of indeterminacy are specific theories concerned with semantic indeterminacy or structural indeterminacy? These questions will be addressed to the extent they are relevant to d'Aspremont's texts.

d'Aspremont's monograph seems to be concerned with semantic indeterminacy. It is a distinctly, and unsurprisingly, Hartian variant ${ }^{\text {IO2 }}$ that is concerned with the relative open-endedness of language (I39). It contends that the words or expressions that comprise legal rules have a 'core' meaning and are to this extent relatively determinate, and equally that such words possess a 'penumbra of uncertainty', and are to some extent indeterminate. ${ }^{\text {Io3 }}$ CLS would disagree with this definition

го There are two factors that lead to this. First, in several key passages on indeterminacy and the social thesis, d'Aspremont does not state that he is focusing on semantic indeterminacy (I4O-I4I); the term is used as if it is self-explanatory (I4I). This would not be problematic given that a Hartian inference can be reasonably made given d'Aspremont's thesis, but for d'Aspremont seeking to respond to and engage with the works of Koskenniemi and his critics (this is especially the case in his neo-positivism project, see d'Aspremont and Kammerhofer, Introduction). Second, d'Aspremont goes on to assert that he 'leaves intact some of the objections of the critique inspired by CLS and deconstruction. In particular, the social thesis, by easing the indeterminacy of the source thesis by grounding it in social practice, only helps contain indeterminacy at the level of law-ascertainment but does not purport to allay the contradictions of legal argumentation.' (2 I8) Does this mean that d'Aspremont believes that the structural indeterminacy of CLS only attaches to the application of legal rules and not their ascertainment, and therefore the CLS critique is left intact because it is irrelevant to d'Aspremont's project? 'This reading also emerges from d'Aspremont's later writings on neo-positivism (ibid). Or does it mean that the structural thesis is assumed as a critique that is not challenged in any way by FSIL? Owing to various passages in the book (I39), I presume here that d'Aspremont's focus is only on tempering semantic indeterminacy and the CLS critique is left fully intact (i.e. it applies to ascertainment and application of legal rules). The contrary reading is presumed and critiqued in Singh, Positivism and New Approaches to International Law.

${ }_{102}$ Hart, The Concept of Law, I 24-1 36.

го3 Ibid, I34. 
of Hartian semantic indeterminacy - take Koskenniemi for example. ${ }^{\text {Io4 }}$ But d'Aspremont does not deal with semantic indeterminacy in its totality, merely a variant of it. By this I mean that he bases his approach to semantic indeterminacy on a given, if not fully explored, theory of language and meaning.

Semantic indeterminacy takes on two different meanings within the CLS and Hartian traditions, precisely because both are based on very different theories of language and meaning. Both consider semantic indeterminacy to be concerned with the meaning of words and concepts, but they find indeterminacy - or perhaps as a more neutral term, uncertainty - in the meaning of such words through different processes and in different places. The semantic indeterminacy found in CLS has its roots in Saussurean structural linguistics. ${ }^{\text {○5 }}$ This position argues that (legal) words have no core meaning; there is no meaning intrinsic to the word itself. Rather meaning emerges through its relationship with other words, specifically on the 'formal differences' ${ }^{\text {I06 }}$ between them. It is in some senses the polar opposite to the Hartian approach, for meaning emerges from understanding what a word is not, rather than any ontological understanding of what it is. The common use of a word enables communication, but it does establish a core meaning for a word. This theory of language is dominant in structuralist and linguistic approaches to international law, but its full consequences are not always explored. ${ }^{\text {Io7 }}$ The application of deconstruction as a linguistic theory, in contrast, results in understanding words and texts as continuously self-generating objects, in a continuous process of textual production and reproduction an 'infinite relay or meaning from signifier to signified.' ${ }^{\circ}$ 8 But what we see in Kennedy and Koskenniemi, d'Aspremont's interlocutors, are works of structuralism. Structural linguistic theories are not concerned with maintaining, or even obtaining, a conceptual space for determinacy. It is a theory that argues that indeterminacy permeates both the core and periphery. In the terminology of, but fundamentally contra Hart, the meaning of a word is always found in the 'penumbra', because this is all that exists in the spatial metaphor of a word. Meaning is utterly impermanent, when considered relative to a Hartian approach.

d'Aspremont does little to acknowledge that his understanding of semantic indeterminacy requires a specific theory of language and meaning. This is understandable: one cannot be expected to defend each epistemological position taken. His claim that semantic indeterminacy can be

${ }^{104}$ See his notions of semantic indeterminacy in M Koskenniemi, From Apology to Utopia: The Structure of International Legal Argument (Reissue with a New Epilogue) (CUP 2005), 590-3.

${ }^{\text {Io5 }}$ F Saussure, General Course in Linguistics (R Harris (tr.), Open Court, Chicago I 983 ), 65 et seq.

ro6 Koskenniemi, From Apology to Utopia, 9.

${ }_{107}$ E MacDonald, International Law and Ethics After the Critical Challenge: Framing the Legal within the Post-Foundational (Martinus Nijhoff, Leiden 201 I), 59-63 (critiquing Koskenniemi for not taking seriously enough the effects of Saussurean linguistics for his own project).

ro8 F Jameson, The Prison-House of Language (Princeton University Press I 972), I 82. 
stemmed or tempered, through the social sources thesis, does however depend on accepting and presuming his linguistic theory. But if we acknowledge that there are other forms of semantic indeterminacy, then we understand d'Aspremont's choice as entirely arbitrary. To think of words as having a core, determined by unified social practice, rather than rejecting such a core and thinking of them as the result of a constantly shifting structure based on irreconcilable but mutually dependent contradictions, is arbitrary. This choice cannot be made by recourse to independent criteria or criteria common to both linguistic theory. His choice of linguistic theory in turn determines how he looks at the linguistic and social practices of international law; his empiricism looks to establish convergence in social practice precisely because this is what his linguistic theory demands.

This acknowledgement leaves the reader in the curious position of knowing that d'Aspremont's attempt to stem his variant of semantic indeterminacy is part and parcel of a larger structural indeterminacy critique. Let me explain. The first point of note is that working towards determinacy in one discourse (international law) only throws us into the very real structural indeterminacy of another discourse (linguistics). Structural indeterminacy knows very well that no discourse is determinate. This first step is hidden from view. Rather, d'Aspremont needs his thesis to be perceived as resting on solid, verifiable foundations. The image of determinacy in international law, and the process of working towards it, requires the appearance of determinate epistemological underpinnings. These are found, for Hartian theorists and d'Aspremont, in the empirical promises of inter-subjective findings in social practice data. Finally, indeterminacy is interminable in the abstract. And every theory always has an abstracted premise. Determinations, in practice, do not end indeterminacy but highlight the contingencies and politics of choice. The solid epistemological foundations to combat linguistic indeterminacy only open the door to the structural indeterminacy of another discourse. One cannot but slide from one discourse into another, the last being no more determinate than the next. Any and all claims to a greater determinacy (in international law or elsewhere) is structured by the interminability of this process.

All of this is to say that there is nothing necessary in d'Aspremont's or Hart's approach to semantic indeterminacy; structural indeterminacy not only highlights the contingency of the conceptual choice taken, but also how the aesthetic that one is seeking in one discourse is always seemingly found in another. Determinacy is an idea and aesthetic that will always arrest the potential slippages of structural indeterminacy in highly predictable ways.

\section{Given Foundations of Determinacy}

A point that emerged from the previous section is how determinacy and indeterminacy are constructed concepts; their meanings alter and can be 
manipulated by certain choices in theory. This observation is of import, because they are conceptual categories used to structure our experience of the world. A significant aspect of d'Aspremont's thesis is to make claims about the foundations of both determinacy and indeterminacy, as well as about their relative benefits for international law. For d'Aspremont, clearer, more determinate rules increases law's authority, its normativity, its legitimacy, and ultimately its efficacy (29-32, I 40I45). This complex cocktail of conceptual entailments are all claims to improvement. I have already spoken of the link between determinacy and coherence, but I think the manner in which d'Aspremont valorises its relationship to greater authority, normative and efficacy, is overstated.

International law's 'normativity', 'legitimacy' and 'efficacy' are each complex, multifaceted concepts. Their relationship to determinacy, i.e. greater determinacy means greater returns for such concepts, is arguably being simplified. This reductionism will be taken up here.

The starting point for analysis is acknowledging that the sources doctrine plays a number of different roles within international law. These roles may be performed in tension with each other, and each such role makes different claims of influence on the normativity of international law. ${ }^{109}$ One such role is to govern the creation of norms. ${ }^{\text {II }}{ }^{\circ}$ A second role is the ability of sources to generate ascertainment criteria that may continuously incorporate contemporary law-making practices. The claim to new sources must, normally, be shoehorned into traditional conceptions. A third role, dominant throughout FSIL, is to determine what is law and what is not. Each of these various roles are equally necessary to the discipline's legitimacy, efficacy and indeed, continuity. But the first two roles require an appreciation of indeterminacy and a not so stringently formalized approach to sources doctrine marked by a respect for loose abstract categories. The silent engine of international law is custom, and it functions in precisely this way, but d'Aspremont would have us do away with it. The legitimacy of the discipline and its efficacy, and perhaps at times its normative pull, is often sustained through increasingly indeterminate and a not-so-formal sources doctrine; the appearance of formality, the myth, is a necessary, indeed indispensible, requirement for the discipline.

\footnotetext{
ro9 Koskenniemi's definition of his indeterminacy ought to be born in mind when considering the various reasons and roles of the sources doctrine in this paragraph: 'And because no rule is more important than the reason for which it is enacted, even the most unambiguous rule is infected by the disagreements that concern how that reason is to be understood and how it ranks with competing ones' Koskenniemi, From Apology to Utopia, 59 I.

по R Jennings, 'What is International Law and How do we Tell it when we See it', (I980) 37 Annuaire Suisse de Droit International 59, 60 ('It should be remembered at the outset that in considering the sources of international law, we are looking not only at the test of validity of law - the touchstone of what is law and what it is not - but also at the ways in which law is made and changed.')
} 
The problem is with d'Aspremont's argumentative trope, in particular the predisposition to having an adversary and needing to overcome it. Determinacy and indeterminacy are for him conceptual opposites. They ought also to be regarded as rhetorical strategies. Their functions and prospects depend on which of the various roles the sources doctrine is set to perform. The point here is that these opposing sensibilities are both required: the narrative ought not to be the triumph or definitive preference of one over the other, but rather an appreciation that their persistent contradiction and tension is central to, and possibly a requisite for, international law's normativity, legitimacy and efficacy.

\section{Comments on Method: Ideological Arrests of the Social Thesis}

The task now is to highlight how d'Aspremont's primary thesis is rife with some persistent, and at times irreconcilable, tensions. Some of these are accepted and he works dialectically, some of these are denied, and some of these are hidden from view due to the FSIL's narrative tropes. I explore these to expose the ideological dimensions that lie at the edges of d'Aspremont's FSIL. The 'strategies of containment' that he employs are laid bare.

Take for instance the competing epistemologies that d'Aspremont premises his formalism upon. On the one hand his formal source thesis finds the legal essence of sources in the 'container' of such rules; they are valorised as rules through a formality that is only found in this essence. ${ }^{\text {II I }}$ On the other hand, his social thesis sees sources as fact, where rules are determined by social practice (or feeling). One is premised on an epistemology of philosophical idealism and the other on realism. ${ }^{\text {II }}$ These have long been conflicting traditions of thought that are often mirrored throughout social theory and international legal thought. Even at the level of epistemology we see operations of structural indeterminacy. ${ }^{\mathrm{II} 3} \mathrm{FSIL}$ artificially arrests this indeterminacy with a circular $\operatorname{logic}($ I 95$) .{ }^{\text {II }}$

I I In contrast to Hart's own sources thesis, d'Aspremont's source thesis is normative - it seeks to make source rules more formal than they are, see Hart, The Concept of Law, I29-I30.

${ }_{\text {I } 2} \mathrm{~T}$ Nagel, 'Subjective and Objective' in J Rajchman and C West (eds.), Post-Analytic Philosophy (Columbia University Press i 985) 31, $38-46$.

II3 For an overview of these considerations see Koskenniemi, From Apology to Utopia, 5 I6-52 I.

II It should be noted that d'Aspremont's social thesis plays both a normative and descriptive role in his projects. A separate critique can be made that the normative element of his social thesis (as outlined in FSIL) undermines the descriptive functioning of the source thesis in his neo-positivist project in ILP. In FSIL, the social thesis is distinctly normative, in that it is used solely as a method to make more formal sources, more determinate (I92-I94, I97, 2I3). In ILP, however, d'Aspremont's neo-positivist project uses the social thesis in a purely descriptive manner. It is used to determine what the law is, buttressing the central positivist proposition that what the law is, is in no way dependent on what the law should be. Determinacy is not imposed, but rather uncovered. The normative social source thesis found in FSIL runs contrary to the tenets of d'Aspremont's later neo-positivist argument. This is further explored in Singh, Positivism and New Approaches to International Law. 
The second epistemological tension that seems to run through FSIL's conceptual framework is between "objective" and "subjective" realism. d'Aspremont's theory of language, as used in his social thesis, favours the former. But he ultimately rests the same thesis on a 'shared feeling of applying the same [law-ascertainment] criteria' (20I) among law-applying authorities; and approach that favours the latter. The concern is that once these competing theoretical and epistemological bases are taken seriously, and meshed together, as d'Aspremont does in his social thesis, they can only destabilise each other's foundations. Let me explain.

Relying on a specific theory of language, d'Aspremont argues that 'the meaning of formal law-ascertainment criteria arises out of their convergence in use' (197, original emphasis). Following Wittgenstein he states 'clarification of the meaning of words ... is all about how the participants in human activities conduct such a clarification... [i]t is how the word I used that will teach us the meaning of the word' (I98-I 99). If meaning rests on use, and a specific intersubjective communitarian use, it must rest on expression. To determine use and expression, d'Aspremont has to have recourse, according to this same theory of language, to 'the practice of law-applying authorities' ( 199 , emphasis added). Of course there cannot be absolute consistency in practice, merely coherence. To examine practice is to undertake an "objective" inquiry; it is distinctly empirical, measurable and appreciates the intricacies of sociological inquiry.

However, d'Aspremont then makes another move:

Yet, concurring with Wittgenstein and subsequently, Hart and rejecting Dworkin's semantic sting objection, I argue that the social foundation of formalism in the ascertainment of international legal rules does not call for actual, total, and absolute agreement among law-applying authorities. It essentially requires a shared feeling of applying the same criteria... such a feeling will necessarily hinge on their respective understandings of formal law-ascertainment criteria dovetailing to a reasonable extent. (201, original emphasis, footnotes omitted $)^{115}$

The "objective" empiricism that we initially see form the basis of his social thesis is replaced by the abstract and effectively immeasurable and abstracted requirement of feeling. What we see in the phenomenological turn is an epistemology premised on a Humean "subjective" realism. And even in this turn, d'Aspremont deprives us of any conceptual tools with which to order the experiences and feelings of others, without which this sensory world is reduced to chaos. The creeping, but

\footnotetext{
I 5 It is curious that d'Aspremont cites Raz in this regard (205, footnote 37 and 21 3, footnote 88), because whilst his work - and d'Aspremont's particular citations of it - considers the possibility for disagreement in the actual use of concepts just as Hart does (and even disagreements about the criteria of application of concepts), he does not seek to bind possible deviations by recourse to some common feeling that disagreeing law-applying authorities may have over their application of a concept.
} 
persistent, concern arising from this observation is precisely the same that MacIntyre had of Hume: sense-empiricism leads 'not to sophistication, but to regression.' ${ }^{\text {II } 6}$

The social thesis is then held together by two conflicting epistemologies, i.e. by two very different understanding of how we can know the international legal world. One presumes that facts can be found in the practice of the social world, and the other rests on our senses, our feelings, of what is in the social world. But how can the latter be shown to actually exist in the social world, and how can they be shown to be shared? And how can former, practice-facts, be shown to exist in our phenomenological world?

The concern is that the social thesis is stretched in opposing directions. If d'Aspremont is loyal to his theory of language and the empirical realism that emerges from it, then he is only able to speak of the shared feelings of law-applying authorities to the extent that these same agents express them in one form or another. It is only upon expression, hence use, that these feelings will have sufficient linguistic or material indicators. On the other hand, if d'Aspremont is loyal to his requirement that the social thesis be determined by appreciating shared feelings, he must abandon his initial theory of language. The phenomenological inquiry requires looking beyond the surface of a word's use and rather insists on looking behind it - what was it intended to mean. This would mean appreciating that a 'linguistic product is not only a socially and historically situated construction which displays an articulated structure, but is also an expression that claims to say something about something; and it is this claim, understood in terms of what is asserted by an expression and what that expression is about, which must be grasped by interpretation.' ${ }^{117}$ An inquiry into feelings requires a hermeneutic approach to language: an appreciation of 'what is being said in what was said', ${ }^{1}{ }^{8}$ what is not said, and what is created in what is said. An analysis of the mere use of words to determine meaning comes to seem superficial and masks the work of ideology.

d'Aspremont's methodology seems to be caught between a rock and a hard place, but this inescapable tension is not opened up to the reader. It is out of reliance on various dialectics that d'Aspremont is able to construct a conceptually coherent vision. And yet this is a coherence that tends to delude, for it contains at its edges precisely the same conceptual schemas that render it simultaneously contingent and necessary.

This leads me to a third remark on the method of d'Aspremont's social thesis. He has almost moved entirely away from Hart, by premising this thesis as dependent on a 'shared feeling among law-applying

ir6 MacIntyre, 'Epistemological Crises, Dramatic Narratives and the Philosophy of Science', I 4.

ir7 J Thompson, 'Language and Ideology: A Framework for Analysis', (1987) 35 The Sociological Review 5I6, 520-52I (underlined emphasis added, italicized emphasis in original).

in 8 Foucault, The Archaeology of Knowledge, 30 (although he rails against such an inquiry). 
authorities'. ${ }^{19}$ This eventually leads him to scupper the possibility of identifying criteria of law-ascertainment because:

Whilst... international society, in spite of its limited institutionalization, is in a position to produce sufficient communitarian semantic for the sake of the social thesis, it seems more questionable whether the current configuration of the international legal society allows the emergence of a sustainable feeling of convergence of the practices of law-ascertainment. Indeed, as explained above, for communitarian semantics to be generated, the mere existence of practice is insufficient. What is needed is a sense by the abovementioned actors that they are using the same criteria and thus the sense that they belong to the same linguistic community.... the problem is thus not really the fragmentation of the production of the social practice but rather the absence of social consciousness among the variety of actors contributing to the production of communitarian semantics. (2 I 3, original emphasis, footnotes omitted)

d'Aspremont uses very different experiential notions, whilst assigning them the same function: 'consciousness', 'feeling' and 'sense'. ${ }^{\text {I20 }}$ This lack is exacerbated because they do an awful lot of legwork. If a shared feeling exists, international law's criteria for law-ascertainment (or Hart's rule of recognition ( I95)) may be identified. But the lack of definition, or criteria of application, becomes even more problematic without any concepts, images, aesthetics or ideas through which they may function to represent the international legal world they seek to represent. As Husserl well knew, without such a methodological apparatus there really is no way to know if a 'feeling' has any connection with the social world beyond an internalised experience. ${ }^{\text {I2I }}$ It is not denied that the 'meaning' that d'Aspremont requires to 'plug' his social thesis can be conveyed by non-linguistic indicators such as feelings, images etc. But in d'Aspremont's FSIL there is no method provided to grasp the

\footnotetext{
I 9 An ungenerous reading of FSIL (precisely because d'Aspremont calls it a Hartian thesis) may argue that he has misread and misapplied Hart. For Hart and for Raz, there may be disagreement and deviations from the application and use of the rule of recognition (what d'Aspremont terms 'law-ascertainment criteria'). From the internal point of view, this rule of recognition is determined by the acceptance and use of its standards by officials of the legal system. The idea that there is a shared feeling as to what a particular rule is, does not come into the equation; the internal point of view is not dependent on shared feelings of obedience for officials (Hart explicitly rejects this), rather it is dependent on their practice of acceptance and use. Any perceived deviation, due to confusion in meaning, does not negate the practice, because coherence does specific reductive work. Determination of whether the rule of recognition is a common standard amongst legal officials is determined by their practice. See specifically, Hart, The Concept of Law, 89-90, I I 5-I I 7; J Raz, 'The Nature and Theory of Law' in J Coleman (ed.), Hart's Postscript: Essays on the Postscript to 'The Concept of Law' (Oxford, 200I) I, I 8-20; contra d'Aspremont's argument in FSIL at 53-55, 20 I. See also note i 6 above.

I20 d'Aspremont speaks of the absence of 'social consciousness' to arguably assert that actors are not aware of their social contribution, but we are not always aware or conscious of everything that is going on around us, let alone in the most habitual of activities. 'Feeling' is arguably broader than consciousness, in that we may not always be aware of its full dimension, in that is may be both a conscious and semi-conscious activity. These distinctions, amongst numerous others, are extremely important, but unexplored by d'Aspremont.

I2I See, E Husserl, Logical Investigations (D Moran (ed.), J Findlay (tr.), Routledge, New York 200 I).
} 
production of this meaning. Does coherence continue to run from the structure of the text, to its aesthetics, to aspects of its practice-based social thesis, all the way to conceptually delineating 'feeling'? Even it did so, it would not go far enough; 'feeling' is left absent of the conditions of its application. ${ }^{122}$ In this sense, it is not operationalized ${ }^{123}$ in a manner that does justice to the methodological requirements of the analytical philosophy and jurisprudential traditions that d'Aspremont seeks to follow. The noteworthy point, however, is that d'Aspremont's text and thesis cannot function if his concept of 'shared feeling' is operationalized. An intellectual arrest has been performed so that the reader can have the appearance of a 'ground' - a foundation upon which to build greater relative determinacy in the sources of international law. If given specificity and the conditions of its application, we would likely see that there are only complex gaps, paradoxes and conflicts in the 'feelings' of law-appliers. The given foundation would, so to speak, begin to shake. Pierre Schlag has called such concepts 'theoretical unmentionables'. These are 'those items within a theory which, by virtue of the identity of the theory, one can say very little about, but which are absolutely necessary for the theory to do its work.' They look 'as if [they have] substance and content - and yet [remain] sufficiently empty that [they] can perform any work required to defend the theory. ${ }^{\text {I2 } 24}$ The point to be made is that d'Aspremont's 'shared feeling' is only a rhetorical trick that pushes his political search for foundations behind the veneer of an apparently graspable theoretical concept. Intellectual arrests perform important rhetorical tasks in any theory. And, yet, you will also see that d'Aspremont's enquiry is artificially arrested in other respects.

In the quote above, we also see d'Aspremont claim that material realities do not undo the social thesis; 'the problem is thus not really the fragmentation of the production of social practice but rather the absence of social consciousness' (213). What would seem to be required is a change in self-aware thinking (consciousness) and shared feeling of the relevant international legal actors. This position couldn't be any more problematic from a Marxist perspective: 'legal relations.... are to be grasped neither from themselves nor from the so-called general development of the human mind, but have their roots in the material conditions of life... It is not the consciousness of men that determines their being, but, on the contrary, their social being that determines their

${ }^{122}$ For an example of how one can flesh out an experiential concept see Winter, A Clearing in the Forest (though he concentrates on imagination). This follows a long line of thinking from Gilbert Ryle onwards, see G Ryle, The Concept of Mind (Hutchinson University Library, London I 949) I04-I07 (on feelings).

${ }^{123}$ It is important to note that this I do not use 'operationalized' in the same sense that Herbert Marcuse used it for concepts, see H Marcuse, One-Dimensional Man: Studies in the Ideology of Advanced Industrial Society (D Kellner (int.), Routledge, London $2^{\text {nd }}$ edn. I99 I) Io7-I I I.

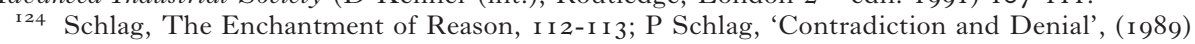
87 Michigan Law Review I 2 I 6. 
consciousness. ${ }^{\text {I25 }}$ I do not assert that d'Aspremont ought to be more of an intellectual Marxist, nor even that Marx's insight has to be right. More simply, I argue that d'Aspremont does not take seriously insights he later made in a 2012 editorial. This has specific consequences for his methodology. There he was concerned with the international legal scholarship and not law-applying authorities, ${ }^{\text {I26 }}$ but he made two points of relevance to both social systems.

First, the use of language is 'informed by the current structure (and membership) of the interpretive community of international law', ${ }^{127}$ it 'unfolds not in a social vacuum, but rather against the backdrop of a well-organized social system. ${ }^{\text {I28 }}$ Such a social system provides 'the protocols and constraints that shape the competition for naming, i29 but is also shaped by 'funding made available' and its 'labour market' ${ }^{1}{ }^{\circ}$ Second, d'Aspremont states that the use of language is about 'the struggle for interpretive authority and persuasiveness', ${ }^{13 \text { r }}$ and this may at points rise to the level of the 'structural inevitability of... interpretive competition... a fact of life inherent in a community.' ${ }^{132}$ But d'Aspremont was equally adamant that this observation and its application to the practice of law-applying authorities would not 'lead to a total rejection of the internal point of view... [and that it] does not necessarily entail an abandonment of internal determinants of legality.' ${ }^{\prime 33}$

The ruptures and contradictions in d'Aspremont's thought between $F S I L$ and his 2012 editorial are countless - from a near complete shift in intellectual and methodological lineages, to a shift from romantic-comic disposition to that of pragmatic cynicism, to another shift from his scepticism of the social thesis in FSIL to his ardent defence of it a year later. But the numerous ruptures and contradictions are useful if only to highlight the series of strategic arrests in his FSIL method. Each of the stated observations in the previous paragraph have the same specific consequence: they require d'Aspremont to reject his own contention that 'the problem is thus not really the fragmentation of the production of social practice but rather the absence of social consciousness' (213). If language is produced and received in specific social conditions, it ought to be clear that the same is true of thoughts and feelings. To an extent

${ }^{125}$ K Marx, 'Preface to a Critique of Political Economy' in K Marx, Karl Marx: Selected Writings (D McLeilan (ed.), OUP, $2^{\text {nd }}$ edn. 2000) $424,425$.

${ }_{126}$ d'Aspremont, Wording, $578,582-584$ ('The social constraints that hinder the moves of international legal scholars are too different from those of international judges. This is both the cause and consequence of the fact that they belong to two different - albeit intertwined - subgroups of the interpretive community of international law.' Ibid, 584)

${ }^{127}$ Ibid, 577.

${ }^{128}$ Ibid, 585 .

129 Ibid.

I3० Ibid, 588 .

${ }^{3}$ I Ibid, 582 .

${ }^{132}$ Ibid, 598 .

${ }^{133}$ Ibid, 583 (footnotes omitted). 
Marx's observations hold true (the term 'determined' is perhaps an overstatement of the case). The problem for the social thesis is therefore one of both social practice and absence of a shared feeling, or social consciousness. This elementary observation is complemented by another. If in a fragmented social context (such as international legal scholarship and academia), we find structural conflict, competition and struggle for authority in the use of language, then the potential areas of intersubjectivity and community are greatly diminished. To be sure the structural conditions of international law-applying institutions may be different, but one can agree that their fragmented nature has led to linguistic and symbolic competition. ${ }^{\text {I34 }}$ The point is simply that this has the inherent potential to defeat the viability of the social thesis: ${ }^{\mathrm{I} 5}$ 'the fragmentation of the production of social practice' has to be, contra d'Aspremont, an essential part of the problem.

The pressing concern I have is that d'Aspremont's method is arrested at the precise points at which it could potentially question or, more importantly, undermine or subvert the text's and his thesis' functional objective of determinacy, and to appropriately grasp its usefulness. He adopts a theory of language that is teleologically premised on determinacy to argue that the meaning of words is premised on a communitarian approach to their use. But at the precise point where he is unsure that sufficient convergence or agreement amongst law-applying authorities may exist (arrest I), he introduces the notion of 'shared feeling' amongst the same actors. He then doesn't assess this concept in terms of its content, objectives or its 'values', or outline the criteria for its application (arrest 2). The initial empirical inquiry into practice (through language) was near-abandoned, supplemented and supervened by an abstract condition of measurement for his social thesis ('feeling'). This latter inquiry is not followed into an empirical enquiry along phenomenological lines (arrest 3); and it is elevated precisely so he does not have to confront those material conditions that would almost certainly defeat, and definitely threaten, his social thesis (as initially premised on practice, i.e. the fragmentation of the production of such practice) (arrest 4). These 'arrests' are methodological injunctions that impose FSIL's strategies of containment. This is no more or less than an ideology that must privilege the status quo, that vision of the world that it sees as 'is'. It will exclude or arrest each enquiry that questions its own conditions of possibility. To the limited extent that there are breaches that it engages its own limits, and even its own impossibility, it will still continue to sustain an

\footnotetext{
I34 M Koskenniemi, 'The Politics of International Law - 20 Years On', (2009) 20 EJIL 7, I I-I 2 (understanding that linguistic competition is endemic to a fragmented legal order).

I35 See e.g. Koskenniemi, From Apology to Utopia, 569-570, 600-6 5 (his notion of structural bias presumes a degree of intersubjectivity at an institutional level: 'there is a structural bias in the relevant legal institutions that makes them serve typical, deeply embedded preferences' (ibid, 607), though he leaves open the question of whether this is possible across the whole range of international law-applying authorities).
} 
unwavering belief in its own possibility. ${ }^{13^{6}}$ After all, its functionalism requires this form of therapy.

\section{Conclusion}

This, evidently, is not a review in the traditional sense. It advocates a new method in international legal thinking, narrative analysis, and applies it to d'Aspremont's FSIL. But while the analysis seeks to remain loyal to d'Aspremont's texts, it aims to highlight its ruptures and its breaks. The very dissociative aesthetic that narrative analysis employs strongly contrasts with the ordered and coherent aesthetic that conditions d'Aspremont's narrative. The purpose is to show how a theory employs subtle and not-so-subtle strategies, tactics and sensibilities and how such aspects of a theory are emotively, intellectually and socially conditioned. It has been demonstrated how dangerous and irresponsible it is to only grasp theories as method for this ignores some of the intricacies of how they work on us and through us. To appreciate them with any degree of reflexivity, it is suggested that at the very least they ought to be grasped and comprehended as narratives. Narrative analysis leads us into the intimate connection between ideas, imagination and action, for the very simple reason that narrative may help capture the complex nature of theorising. I hope narrative analysis will allow us to appreciate that a legal theory is part method, part aesthetics, and part ideology; and most importantly, that it is in each of these parts and the sum of its whole, always historical.

Beyond this abstraction, this article has been about d'Aspremont's $F S I L$, and more broadly, the logic of a returned formalism in European international legal thinking. It has been an engagement with the work of a fine, if evolving, theorist in international law. It is perhaps simplistic to say that FSIL ought to be essential reading for all those interested in contemporary international legal theory. For those with knowledge of the terrain, it is a book whose content will be familiar; much like seeing an old friend after not so many years, with a little cosmetic work fitting of the times. This is a book that seeks to reintroduce the old into the new: a neo-positivism or formalism for a postmodern world. But it is a book that, in many respects, is on the offensive: why a formalist offensive is necessary, what it means for the discipline, and how it is effectuated, are all questions that are addressed in d'Aspremont's project. 